\title{
Seismicity of the Northern Volcanic Zone of Iceland
}

\author{
Páll Einarsson* and Bryndís Brandsdóttir \\ Institute of Earth Sciences, University of Iceland, Reykjavik, Iceland
}

A half century of monitoring of the Northern Volcanic Zone of Iceland, a branch of the North America-Eurasia plate boundary, shows that the seismicity is very unevenly distributed, both in time and space. The four central volcanoes at the boundary, Peistareykir, Krafla, Fremrinámar, and Askja, show persistent but very lowlevel seismicity, spatially coinciding with their high-temperature geothermal systems. On their rift structures, on the other hand, seismicity is almost absent, except during rifting episodes. Krafla went through a rifting episode in 1975-1984 with inflation, interrupted by 20 diking events with extensive rifting, eruptive activity, and intense seismicity along an $80 \mathrm{~km}$ long section of the rift. During inflation periods, the seismicity was contained within the caldera of the volcano, reflecting the inflation level of the magma chamber. Diking events were marked by seismicity propagating away from the volcano into the fissure swarms to the south or north of the volcano, accompanied by rapid deflation

OPEN ACCESS

Edited by:

Derek Keir,

University of Southampton,

United Kingdom

Reviewed by:

Finnigan IIIsley-Kemp,

Victoria University of Wellington,

New Zealand

Luigi Passarelli,

Université de Genève, Switzerland

*Correspondence:

Páll Einarsson

palli@hi.is

Specialty section:

This article was submitted to

Volcanology,

a section of the journa

Frontiers in Earth Science

Received: 13 November 2020

Accepted: 24 February 2021

Published: 26 March 2021

Citation:

Einarsson $P$ and Brandsdóttir $B$ (2021) Seismicity of the Northern

Volcanic Zone of Iceland.

Front. Earth Sci. 9:628967.

doi: 10.3389/feart.2021.628967 of the caldera magma chamber. These events lasted from 1 day to 3 months, and the dike length varied between 1 and $60 \mathrm{~km}$. The area around the Askja volcano is the only section of the Northern Volcanic Zone that shows persistent moderate seismicity. The largest events are located between fissure swarms of adjacent volcanic systems. Detailed relative locations of hypocenters reveal a system of vertical strike-slip faults, forming a conjugate system consistent with minimum principal stress in the direction of spreading across the plate boundary. A diking event into the lower crust was identified in the adjacent fissure swarm at Upptyppingar in 2007-2008. Four nests of anomalously deep earthquakes (10-34 km) have been identified in the Askja region, apparently associated with the movements of magma well below the brittle-ductile transition. Several processes have been pointed out as possible causes of earthquakes in the deformation zone around the plate boundary. These include inflation and deflation of central volcanoes, intrusion of propagating dikes, both laterally and vertically, strike-slip faulting on conjugate fault systems between overlapping fissure swarms, migration of magma in the lower, ductile crust, and geothermal heat mining.

Keywords: Iceland, Northern Volcanic Zone, earthquakes, Krafla volcano, Askja volcano, dike intrusion, rifting, inflation-deflation cycle

\section{INTRODUCTION}

Volcanism in Iceland has its roots in two different processes. The mid-Atlantic plate boundary runs through the country, separating two of the largest lithospheric plates, the North America and the Eurasia plates and spreading at a rate of about $19 \mathrm{~mm} /$ year (e.g., Árnadóttir et al., 2009). At the same time the area is a hotspot fed by a mantle plume centered on the central highlands 
of Iceland but affecting an area much larger than the present extent of the country (e.g., Wolfe et al., 1997). The two processes interact and lead to a high rate of eruptions from about 30 different and active volcanic systems. The rate fluctuates within the range of 20-50 eruptions per century, with 22 eruptions in the last 50 years, for example (Einarsson, 2018). Running a modern society in a highly active area requires substantial monitoring effort. In Iceland the effort is based to a large extent on a combination of two methods to track the pathways and storage of magma in the crust, seismic monitoring and surface deformation studies (Sturkell et al., 2006; Einarsson, 2018; Sigmundsson et al., 2018). The first step in the detection strategy is to identify the volcanic systems that are preparing for an eruption. This includes detecting deviation in behavior from the long-term background seismicity. This is not a trivial task in the tectonic environment of an active plate boundary, where earthquakes are common (Pedersen et al., 2007). Long time series are essential. Once the active systems are identified the next step is to install instrumentation to detect the pressure changes and magma movements within the systems. Fortunately, most of the 30 volcanic systems that have been active in the Holocene are in a passive state at present and do not require intensive attention. The last step in the monitoring and warning process requires the ability to detect and correctly identify the short-term precursors to the initiation of an eruption. This last phase of the precursory activity, when the magma breaks out of its storage volume and propagates toward the surface, is marked by intensified seismic activity and rapid crustal movements. All eruptions in the last few decades in Iceland have been preceded by such detectable shortterm precursors, and in $2 / 3$ of the cases they have led to a warning to the public before the eruption broke out (Einarsson, 2018).

In the present paper, we intend to give an overview of the long-term seismic behavior of one branch of the volcanically active zones of Iceland, the Northern Volcanic Zone (Figure 1), based on the experience of the last several decades, or since sensitive seismic instrumentation was installed, mostly in the early seventies. This zone includes the volcanic systems of Deistareykir, Krafla, Fremrinámar, and Askja, all of which show different seismic characteristics. Krafla went through an episode of magmatic rifting in the period 1975-1984 with many lateral dike intrusions, nine basaltic fissure eruptions, and extensive surface rifting. The Askja area has persistent, intermediate-level seismicity that has been ascribed to several different tectonic and magmatic processes in the crust. All the systems have low-level, persistent seismicity that correlates spatially with the surface manifestation of hydrothermal systems.

\section{VOLCANIC ZONES AND VOLCANIC SYSTEMS OF ICELAND}

A good part of the volcanism in Iceland takes place at or near the mid-Atlantic plate boundary. As it crosses the Iceland platform, the plate boundary breaks up into a series of segments, rifts, transforms and oblique segments. In some places the boundary branches out and small microplates or tectonic blocks are formed that may move independently of the large plates. The spreading across the plate boundary in South Iceland is divided between two sub-parallel branches, the Western and Eastern Volcanic Zones. The two zones are connected by a transform zone, the South Iceland Seismic Zone. Together with the Central Iceland Volcanic Zone these branches demarcate a microplate, the Hreppar Microplate (Einarsson, 2008), a diamond-shaped, $100 \times$ $100 \mathrm{~km}$ crustal block that appears to move independently of the major plates. The $19 \mathrm{~mm} /$ year total spreading rate is partitioned unevenly among the two divergent branches (Sigmundsson et al., 1995; La Femina et al., 2005), about one-fifth taken up by the western branch and the rest by the eastern branch. The plate divergence in the northern part of Iceland takes place along a single boundary, the Northern Volcanic Zone (e.g., Drouin et al., 2017a). Oblique segments also exist and contain volcanism and strike-slip tectonism in close proximity to each other. The Reykjanes Peninsula Rift (RPR) and the offshore Grímsey Oblique Rift (GOR) are examples of this type. The structure of the divergent branches of the boundary is characterized by rifting. Normal faults, fissures, and eruptive fissures are abundant and are arranged into swarms that form volcanic systems together with one or two central volcanoes, where the volcanic activity is more concentrated than elsewhere (Saemundsson, 1974, 1978).

In addition to the plate boundary volcanism there are three zones of intraplate volcanism, or flank zones. The Snaefellsnes Volcanic Zone, the South Iceland group of volcanoes, and the Öraefajökull-Snaefell zone located east of the Eastern Volcanic Zone.

Note on terminology: The term "fissure swarm" in Iceland is used for an array of fissures and normal faults. Similar structure is called "rift zone" in other areas, e.g., in Hawaii. A "rift zone" in Iceland consists of several volcanic systems, i.e., several subparallel fissure swarms.

\section{THE NORTHERN VOLCANIC ZONE}

This branch of the plate boundary separates the two major plates, the North America and the Eurasia plates. The vector of plate separation is slightly oblique to the trend of the zone, so the volcanic systems are arranged en echelon. Most of the swarms extend along a large portion of the zone, so crossing the boundary one may have to cross a $50 \mathrm{~km}$ wide deformation zone with four or five semi-parallel fissure swarms. This means that the total plate velocity is partitioned between several fissure swarms and is not taken up by only one. The principal volcanic systems are Peistareykir, Krafla, Fremrinámar, and Askja, all accompanied by impressive fissure swarms (Saemundsson, 1974; Hjartardóttir et al., 2016a). Sometimes two more are added to the list, Heiðarsporður and Hrúthálsar, both with traces of evolved rocks but limited fissure swarms (Saemundsson, 1991).

The seismicity of the Icelandic rift zones is highly clustered, both in time and space (Einarsson, 1991a). Most of the seismicity occurs at the central volcanoes, whereas the fissure swarms are generally very quiet. And the seismicity of the central volcanoes is only moderate, except during major volcanotectonic events or episodes. Thus, the background seismicity of the Northern Volcanic Zone for the last few decades has 


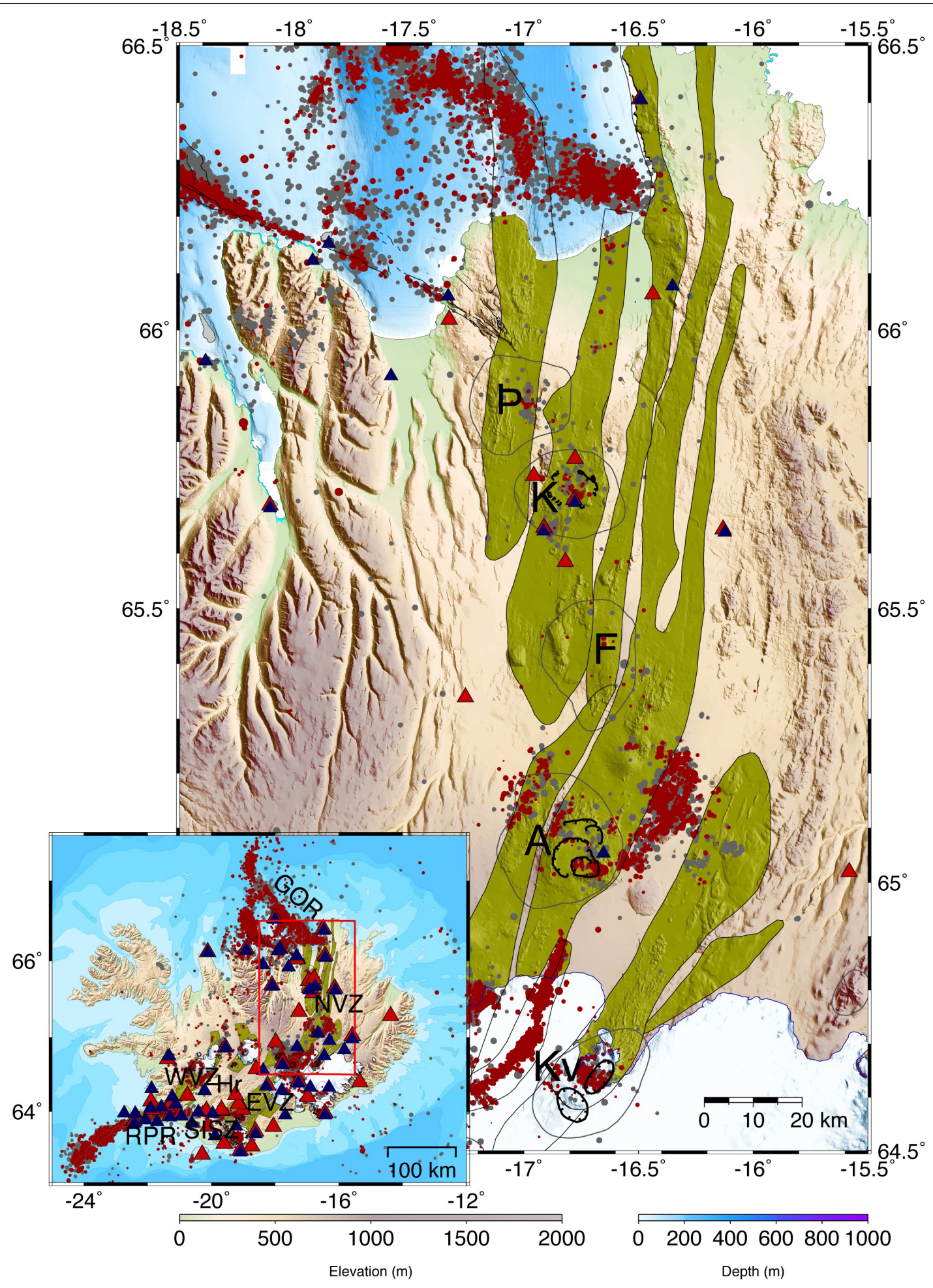

FIGURE 1 | The Northern Volcanic Zone of Iceland. Volcanic systems are shown (Hjartardóttir et al., 2012), usually named by the main central volcano: P Peistareykir, K Krafla, F Fremrinámar, A Askja, and Kv Kverkfjöll. Their respective fissure swarms (or rift zones) are shown in yellow. Epicenters of earthquakes for the period 1995-2020, shown with black and red dots, are from the Icelandic Meteorological Office. Black dots are epicenters of the period 1995-2010 and M $\geq 2.0$, and red dots are events of 2011-2020 with M $\geq 1.5$. Shown are the Northern, Eastern, and Western Volcanic Zones (NVZ, EVZ, and WVZ), the Reykjanes Peninsula Rift (RPR), the South Iceland Seismic Zone (SISZ), the Grímsey Oblique Rift (GOR), and the Hreppar Microplate (Hr). Digital elevation and bathymetric models from the National Land Survey of Iceland and the Hydrographic Survey of the Icelandic Coast Guard. Seismic stations are shown with triangles, red for the Krafla period 1974-1994 and black for the digital stations 1995-2020. 

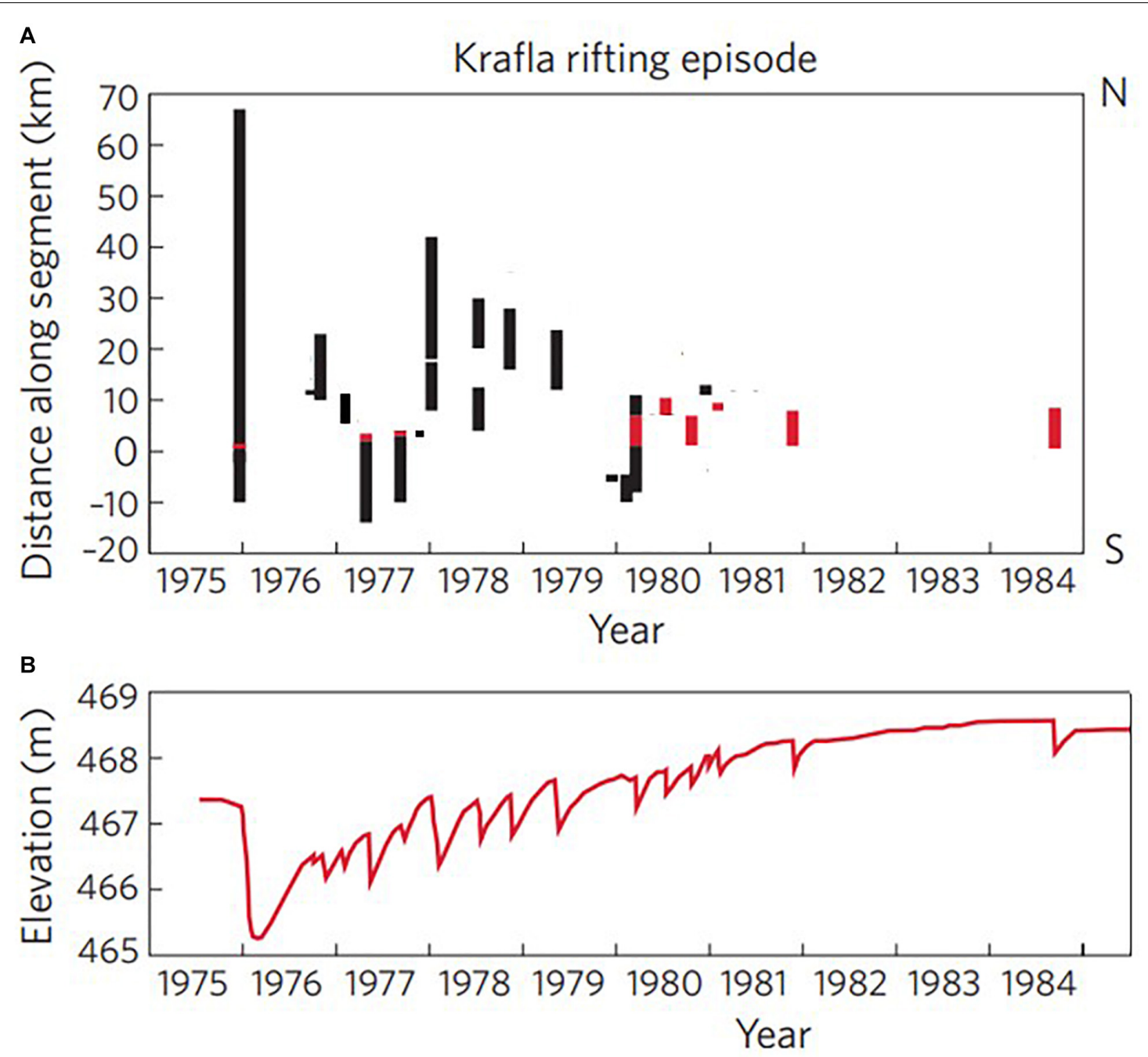

FIGURE 2 | Timeline of the Krafla rifting episode. (A) Distance of the rifting section of the fissure swarm during deflation of the caldera. Red bars indicate the occurrence and location of eruptions. (B) Elevation of the caldera center (modified from Einarsson, 1991b, and Wright et al., 2012). The graph is based on data from leveling, interpolated with the help of a water level tilt meter record. The activity ended with the Krafla volcano in an inflated state.

been characterized by weak seismicity of the main central volcanoes and moderate seismicity of an area east of the Askja volcano, $15 \times 20 \mathrm{~km}$ in dimensions. The main fissure swarms of the rift, with their impressive normal faults and fissures, are seismically virtually inactive, however, even at the microearthquake level. The weak seismicity of the central volcanoes of Peistareykir, Fremrinámar, and part of the Askja activity, appears to be spatially linked with the high-temperature geothermal areas of these volcanoes. Geothermal heat mining and cooling contraction, or other geothermal processes, may be responsible for this seismicity (Einarsson, 1991a). It is also noteworthy that silicic rocks are associated with these sites and may play a part in the causal process.

The most significant seismic activity of the Northern Volcanic Zone in the last decades took place in two areas: The Krafla volcanic system during the major magmato-tectonic events of 1975-1984 and in the Askja area persistently during the whole period of observations. These events will be discussed in Sections Krafla and Askja, respectively.

The monitoring capacity for earthquakes in the Northern Volcanic Zone has improved greatly during the last half century. An overview of the history of the seismograph system is given by Einarsson and Jakobsson (2020). The first network in North Iceland with the capability to distinguish between the activities of different volcanoes was installed in 1974, just in time to detect the beginning of the Krafla rifting episode (Einarsson, 2018). The network had 6-11 stations within $80 \mathrm{~km}$ distance from Krafla (Figure 1), and earthquakes down to magnitude 2 could be located with uncertainties less than 1-2 km (Einarsson, 1991a). The network was augmented by portable seismographs during critical times if conditions allowed, which was not very often. The studies of S-wave attenuation (Einarsson, 1978) and of the swarms of September 1977 and July 1980 (Brandsdóttir and Einarsson, 1979; Einarsson and Brandsdóttir, 1980) were 
done with a network with a few extra stations added to the permanent network. The hypocentral locations were calculated by inversion programs like HYPOELLIPSE by Lahr and Ward (1976) and subsequent inversion programs developed at the USGS in Menlo Park, CA. Crustal velocity structure was based on the extensive work of Pálmason (1963) and calibrated with explosions in a crater lake (Einarsson, 1978). The accuracy of depth determinations was uneven within the network. Close to the seismic stations the uncertainty was of the order of $1 \mathrm{~km}$, but farther away it was not so good. Therefore, the depth determination of activity close to the central volcano and the southern fissure swarm was good, but in a large part of the uninhabited northern fissure swarm the depth is not well constrained.

The first epicentral maps for the whole zone reveal the clustered seismic activity, with most of the background seismicity occurring in the central volcanoes (Einarsson, 1991a). It also showed the unexplained persistent seismic activity in the volcanic zone east of the Askja volcano.

After 1990, the seismic network in the country was gradually replaced by a digital, semi-automated network (Stefánsson et al., 1993) (Figure 1), and the last analog seismograph station was decommissioned in 2010. The Askja seismicity attracted attention, and in 2005 and following years, the permanent network was augmented with temporary stations around Askja, by initiative from Cambridge University. The level of detection was lowered by up to two magnitude units (Greenfield et al., 2018), with a stream of research papers on this remarkable cluster of activity within the Northern Volcanic Zone (e.g., Soosalu et al., 2009; White et al., 2011; Green et al., 2014, 2015).

\section{Krafla}

The Krafla volcanic system consists of a central volcano with a $10 \times 8 \mathrm{~km}$ caldera of about $110 \mathrm{ka}$ age, partly buried by later lavas (Saemundsson, 1991; Rooyakkers et al., 2020). The caldera is transected by fissure swarms that extend about $45 \mathrm{~km}$ to the south and $60 \mathrm{~km}$ to the north of the volcano, subparallel to the plate boundary. The only known previous historic rifting episode occurred in 1724-1746, with extensive rifting, apparently mainly in the southern fissure swarm, and several fissure eruptions in the caldera and southern fissure swarm (Saemundsson, 1991; Hjartardóttir et al., 2012). The big lessons in volcano seismicity were provided by the Krafla magmatic episode that occurred in 1974-1989 (Björnsson et al., 1977; Tryggvason, 1984; Einarsson, 1991b; Buck et al., 2006). During this time interval about twenty inflation-deflation cycles of the Krafla central volcano were detected (Figure $\mathbf{2}$ and Table 1). During inflation of the central volcano the seismicity was limited to the caldera (Figure 3) and generally increased toward the end of the inflation phase. In several cases it can be demonstrated to follow the Kaiser effect (Heimisson et al., 2015), i.e., the seismicity was at a minimum until the inflation level exceeded the maximum level of the previous inflation. Then, it increased abruptly. An important corollary is that inflation and deflation of a caldera can occur without significant or detectable change in seismicity. This range of aseismic inflation-deflation was of the order of one meter vertical displacement at the center. A high proportion of the caldera earthquakes showed anomalously small S-waves, indicative of S-wave shadowing by a magma body (Einarsson, 1978), later confirmed by seismic profiling and seismic imaging of the caldera (Brandsdóttir and Menke, 1992; Schuler et al., 2015). Most of the caldera earthquakes originated in the uppermost $3 \mathrm{~km}$ of the crust, below which an aseismic layer extended to a depth of $7 \mathrm{~km}$. Several earthquakes at $7 \mathrm{~km}$ depth delivered S-waves to regional seismic stations, indicating a bottom to the attenuating body (Einarsson, 1978).

During the deflation part of the cycle, the fissure swarm was activated (Figure 3) with propagating earthquakes and largescale rifting (Brandsdóttir and Einarsson, 1979; Einarsson and Brandsdóttir, 1980).

The activity can be divided into phases, each of which was accompanied by characteristic seismicity.

\section{The Preparatory Phase, 1974-1975}

A newly installed seismograph system began picking up events originating within the caldera of Krafla in the winter of 19741975. This was unexpected. No significant activity had been known there before, and the increase was confirmed by local residents who had never before felt local earthquakes. This increase was limited to the caldera. The issue was politically

TABLE 1 | Dikes and deflation events of the Krafla episode.

\begin{tabular}{|c|c|c|c|c|c|c|c|c|c|c|}
\hline $\mathbf{Y}$ & $\mathbf{M}$ & D & Dur & Dir & $\begin{array}{c}\mathrm{L} \\
(\mathrm{km})\end{array}$ & $\begin{array}{c}\text { Speed } \\
(\mathrm{m} / \mathrm{s})\end{array}$ & $\begin{array}{c}\text { Defl. } \\
\text { cm }\end{array}$ & Erupt. & Prec.t & $\begin{array}{c}\text { Vol. lava } \\
\mathrm{Mm}^{3}\end{array}$ \\
\hline 1975 & 12 & 20 & $90 \mathrm{~d}$ & $\mathrm{~S}, \mathrm{~N}$ & 60 & & 203 & Y & $15 \mathrm{~m}$ & Small \\
\hline 1976 & 09 & 29 & $5 d$ & $\mathrm{~N}$ & 12 & & 14 & & & \\
\hline 1976 & 10 & 31 & $2 d$ & $N$ & 24 & & 57 & & & \\
\hline 1977 & 01 & 20 & $2 d$ & $\mathrm{~N}$ & 10 & & 29 & & & \\
\hline 1977 & 04 & 27 & $2 d$ & $S$ & 17 & & 77 & $Y$ & $(1 \mathrm{~h})$ & Small \\
\hline 1977 & 09 & 08 & $1 d$ & $S$ & 13 & 0.35 & 21 & $Y$ & $21 / 4 h$ & Small \\
\hline 1977 & 11 & 02 & $1 d$ & $N$ & $<3$ & & $<4$ & & & \\
\hline 1978 & 01 & 06 & $20 d$ & $\mathrm{~N}$ & 45 & 0.2 & 105 & & & \\
\hline 1978 & 07 & 10 & $3 d$ & $N$ & 25 & 0.5 & 57 & & & \\
\hline 1978 & 11 & 10 & $5 d$ & $N$ & 18 & & 64 & & & \\
\hline 1979 & 05 & 13 & $5 d$ & $N$ & 24 & & 84 & & & \\
\hline 1979 & 12 & 02 & $6 d$ & S? & $4 ?$ & & 3 & & & \\
\hline 1980 & 02 & 10 & $10 \mathrm{~d}$ & $S$ & 10 & & 10 & & & \\
\hline 1980 & 03 & 16 & $1 d$ & $\mathrm{~N}, \mathrm{~S}$ & 20 & 0.9 & 38 & Y & $65 \mathrm{~m}$ & Small \\
\hline 1980 & 07 & 10 & $6 \mathrm{~d}$ & $N$ & 9 & & 40 & Y & $5 \mathrm{~h}$ & 30 \\
\hline 1980 & 10 & 18 & $5 d$ & $N$ & 7 & & 30 & $Y$ & $82 \mathrm{~m}$ & 40 \\
\hline 1980 & 12 & 24 & $4 d$ & $N$ & 10 & & 10 & & & \\
\hline 1981 & 01 & 30 & $5 d$ & $N$ & 6 & & 27 & Y & $7 \mathrm{~h}$ & 32 \\
\hline 1981 & 11 & 18 & $5 d$ & $N$ & 8 & 1.8 & 50 & Y & $76 \mathrm{~m}$ & 40 \\
\hline 1984 & 09 & 04 & $14 d$ & $N$ & 8.5 & 0.6 & 55 & $Y$ & $264 \mathrm{~m}$ & 80 \\
\hline
\end{tabular}

Characteristics of the 20 deflation/diking events of Krafla 1975-1984: Date of the beginning, duration of the event from the beginning of deflation until inflation sets in again, direction of propagation into the $N$ or $S$ fissure swarms, length of the dike measured from the center of the caldera to the distal end of the epicenter distribution (Einarsson, 1991b), maximum speed of propagation, vertical subsidence at the center of deflation (Björnsson and Eysteinsson, 1998), eruption, and precursor time from the beginning of deflation until an eruption begins (Einarsson, 2018). 


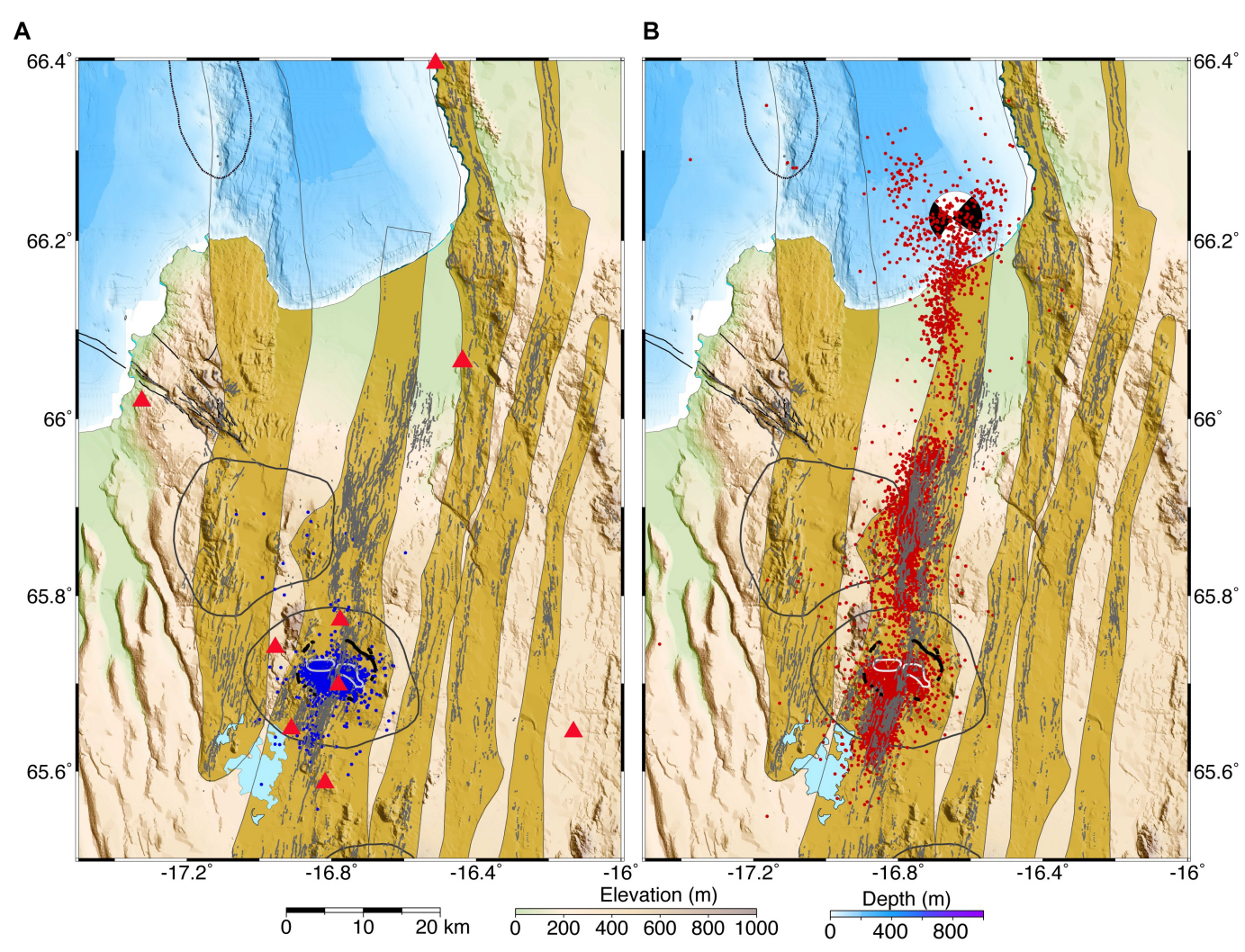

FIGURE 3 | Maps of epicenters during inflation periods of Krafla 1975-1984 in blue (A) and during deflation periods of the caldera in red (B). Focal mechanism of the Kópasker earthquake $\left(M_{S}\right.$ 6.4) that occurred at the rift-transform intersection during the first rifting event is shown (Einarsson, 1986). Seismic stations are shown with red triangles in (A). Digital elevation and bathymetric models from the National Land Survey of Iceland and the Hydrographic Survey of the Icelandic Coast Guard.

very sensitive because a new and controversial power station was under construction within the caldera.

\section{The Initial Rifting Event, December 1975-March 1976}

A new phase of the activity began suddenly on December 20 when a small basaltic fissure eruption broke out in the center of the caldera, preceded by only $15 \mathrm{~min}$ of intense earthquake activity (Einarsson, 2018) that was detected by seismic stations throughout Iceland. The earthquake activity soon propagated out of the caldera, first to the south and then to the north. The eruption then came to an end, and only lasted about $2 \mathrm{~h}$. The activity south of the caldera lasted a few hours, but the earthquakes north of the caldera kept propagating for several days until they reached the intersection of the fissure swarm with the Grímsey Oblique Rift offshore. All together about $60 \mathrm{~km}$ section of the fissure swarms was activated in this event. The earthquakes continued, however, and so did the deflation of the caldera. Large-scale rifting was observed along the northern end of the fissure swarm.

On January 13 a magnitude 6.4 earthquake occurred offshore at the intersection with the Grímsey Oblique Rift. The focal mechanism indicated strike-slip faulting (Einarsson, 1986, 1987). The earthquake caused considerable damage in the surrounding area, particularly in the Kópasker village. The earthquake was clearly triggered by the widening of the Krafla fissure swarm that was still going on immediately to the south (e.g., Passarelli et al., 2013).

The initial rifting event ended in March, both the deflation of the caldera and the earthquake swarm and rifting at the northern end of the fissure swarm. Soon after that the caldera began inflating.

\section{Intrusive Activity North of the Caldera, September 1976-January 1977}

The re-inflation of the caldera was an indication that the activity at Krafla had not come to an end. This was confirmed when earthquake activity in the caldera began increasing in the summer of 1976 (Björnsson et al., 1977; Heimisson et al., 2015). The number of detected earthquakes in the caldera increased from a few events per day to more than a hundred. This activity suddenly stopped in September, when the caldera began to slowly subside. A flurry of earthquakes was detected in the fissure swarm north of the caldera indicating an intrusion in that area. This event only lasted five days and the caldera started inflating again. Much more dramatic intrusive activity followed, in October 1976 and January 1977, after the inflation level in the caldera had reached and exceeded the previous maxima, reached before the September deflation. This activity was accompanied by intense earthquake swarms and surface rifting in the northern fissure swarm. 


\section{Intrusive Activity in the Southern Fissure Swarm, April and September 1977}

The caldera seismicity was very low after the deflation of January 1977 , only a few detected events per day. It remained low despite re-inflation of the caldera. When the inflation level exceeded the previous maximum, however, the seismicity increased rather abruptly. The inflation continued for about two months until finally the magma storage was ruptured, and a dike began propagating from the caldera into the southern fissure swarm. A small eruption began at the northern caldera rim but stopped as soon as the dike began propagating. Extensive surface rifting occurred inside the caldera as well as in the southern fissure swarm (Figure 4).

Inflation of the caldera set in as soon as the April dike became inactive. This inflation (about $1 \mathrm{~m}$, Figure 2) was aseismic and continued until the level of the previous inflation was almost reached. Then, a new diking event began rather abruptly with a small eruption at the northern caldera rim, in the same place as in the previous diking event. The eruption lasted about $2 \mathrm{~h}$. Also this time, the dike propagated southwards, and the eruption came to an end (Brandsdóttir and Einarsson, 1979). A unique event took place when the dike had propagated through the Bjarnarflag geothermal area about $10 \mathrm{~km}$ south of the caldera. One of the drillholes used for power production erupted, punctured a steam pipe, and erupted a few tons of basaltic pumice for a while (Larsen et al., 1979). The dike did not propagate as far as the one in April (Figure 4), but extensive surface rifting was observed in the fissure swarm. The diatomite factory at Bjarnarflag was seriously damaged by the surface ruptures. The hypocentral depth of the earthquakes in the swarms of April and September was also consistent with a shallow intrusion. They occurred down to 3-4 km.

The dike intrusions of 1977 into the southern fissure swarm were accompanied by surface rifting and crustal extension within the caldera. The subsequent inflation of the caldera did therefore not lead to earthquake activity at the same inflation level as before. The correlation between the inflation and earthquake activity in the caldera became weaker (Heimisson et al., 2015).

\section{Intrusions in the Northern Fissure Swarm, 1978-1979}

The inflation following the southern intrusions of 1977 by far exceeded the previous maximum level and was interrupted only by a small deflation event in November. In the beginning of the year 1978 the rate of inflation had decreased, and the caldera seismicity was low. A debate about the possible end of the activity was quickly silenced on January $6^{\text {th }}$ when a new intrusion event began with a slow deflation at the caldera. The rate quickly increased, and earthquakes propagated into the northern fissure swarm. This event turned into the second largest dike intrusion of the Krafla rifting episode, in terms of volume, distance, and duration (Table 1). No eruption accompanied this intrusion but rifting occurred near the distal end of the dike, where it cut the main road. A re-measurement of a leveling profile there shows that the rifting has the form of a graben of $7 \mathrm{~km}$ width that subsided $1.2 \mathrm{~m}$. The flanks were uplifted by $0.5 \mathrm{~m}$ (Sigurdsson, 1980; Hjartardóttir et al., 2012).
Similar events took place in July and November 1978, and May 1979 (Einarsson and Brandsdóttir, 1980). They were all accompanied by similar amount of deflation, $60-70 \mathrm{~cm}$. The length of the dike became progressively shorter, however, and the surface rifting took place in different parts of the northern fissure swarm (Figure 4). No eruptions occurred but one drill hole within the caldera got clogged during the May 1979 intrusion. Repair and clearing of the hole revealed fresh basaltic glass.

\section{Intrusions Into the Southern Fissure Swarm, February and March 1980}

Inflation during the next seven months was interrupted by a small episode of slow deflation in the beginning of December 1979. A few small earthquakes at the southern caldera rim indicated that magma may have migrated a short distance to the south during this deflation. Inflation resumed and continued until February 10 when a new deflation event began with a swarm of small earthquakes south of the southern caldera rim (Figure 4). The activity slowly migrated southwards with varying intensity. The hypocenters of these earthquakes were unusually deep, between 5 and $7 \mathrm{~km}$, deeper than during the intrusions in the same area in 1977. Very little surface rifting was observed. Apparently, this dike was intruding below the dikes formed in 1977. After ten days of deflation the caldera began inflating again.

The elevation of the caldera just about reached the previous maximum when a new deflation event began rather abruptly on March 16. This time the course of events was very rapid. The rate of deflation was unusually high and vigorous spasmodic tremor was recorded on the seismograph network with increasing amplitude, accompanied by earthquakes. An eruption broke out on a fissure within the caldera $65 \mathrm{~min}$ after the beginning of the deflation. The erupting fissure propagated toward the north, and in $25 \mathrm{~min}$, it had attained a length of $4.5 \mathrm{~km}$. The opening of the fissure was not accompanied by any noticeable increase in seismic activity. The earthquakes kept propagating to the north, however, at least for 5 more kilometers. Then, the events took an unexpected course. A new dike began propagating southwards from the caldera with larger earthquakes than before, exceeding magnitude 3 (Figure 4). This dike followed the same path as the February dike, but at shallower level. The eruption vigor decreased when the new dike began propagating and came to an end. The volume of this eruption was small, but still considerably larger than the three previous eruptions of the episode. It marked the end of the primarily intrusive part of the Krafla magmatotectonic episode.

\section{Eruption Phase, July and October 1980, January and November 1981, and September 1984}

The remaining deflation events at Krafla were mostly eruptive, i.e., most of the mobilized magma found its way to the surface to feed eruption on long fissures within the caldera and adjacent northern fissure swarm. The only exception was a small deflation event in December 1980 when magma apparently was injected into the northern fissure swarm. The five eruptions shared several characteristics, even though the time scale and rate of change were variable. The beginning of the deflation was indistinguishable from what was observed in previous intrusive 


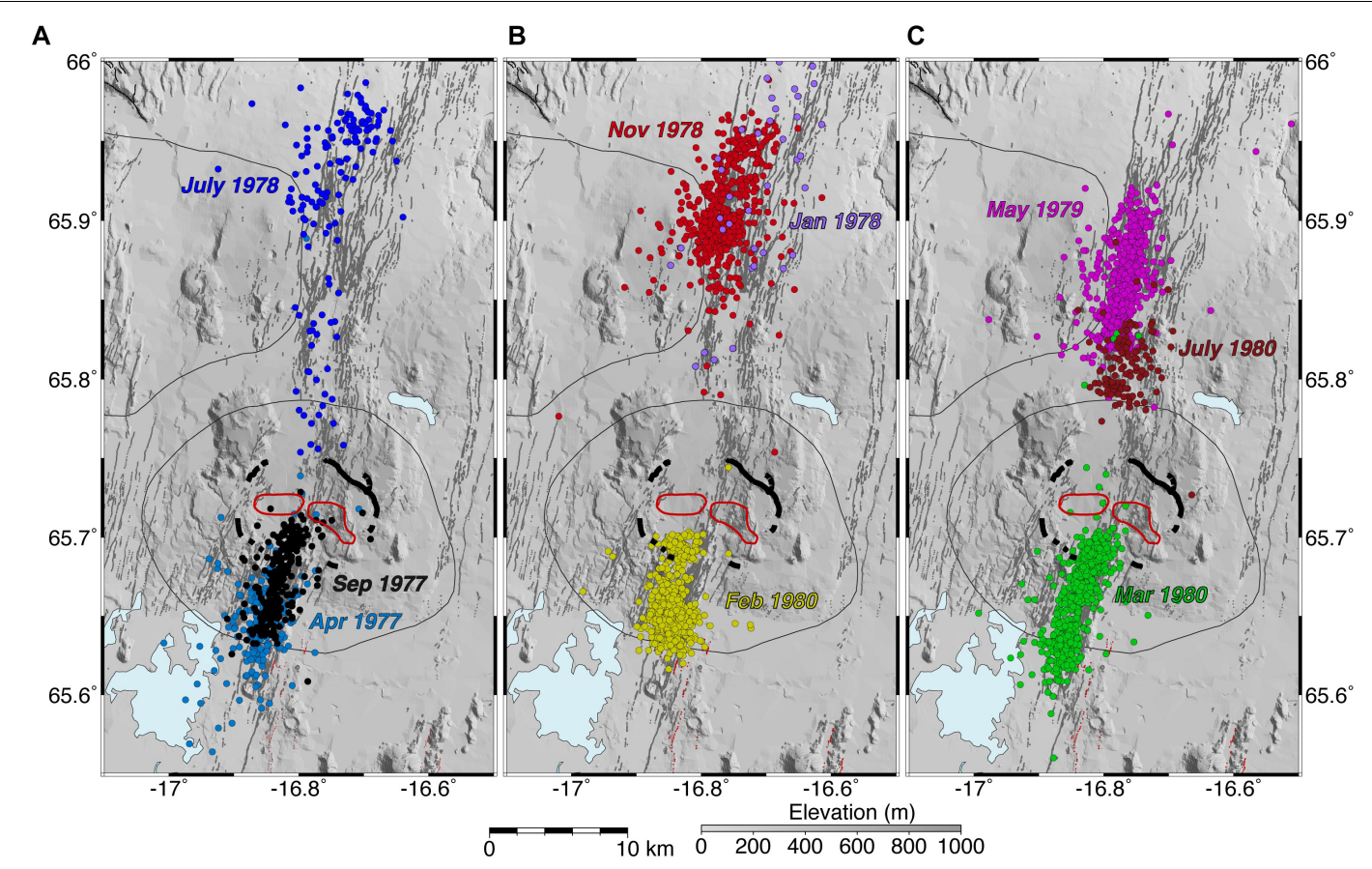

FIGURE 4 | Epicenters during intrusive activity in the fissure swarms of Krafla in April and September 1977, and July 1978 (A); January and November 1978, and February 1980 (B); May 1979, and March and July 1980 (C). The caldera rims of Krafla and the outlines of the central volcanoes are shown for reference. Red lines within the caldera show the outlines of the S-wave shadows (Einarsson, 1978). Faults and fissures are from Hjartardóttir et al. (2016b). Red lines are eruptive fissures. Digital elevation model from the National Land Survey of Iceland.

events. It was not until the dike approached the surface that a difference in seismicity was noticeable. Often low-frequency earthquakes were the last signal that an eruption was about to break out (Einarsson, 2018). Usually, the earthquake activity decreased markedly when the eruption began and remained low during the eruption. The eruptive fissures of two of the eruptions (July 1980 and January 1981) were 4 and $2 \mathrm{~km}$ long, respectively, and located 5-7 km north of the caldera. The other three eruptions took place on much longer fissures, extending from the center of the caldera and $8-9 \mathrm{~km}$ to the north. The eruptions were most vigorous during the first day and then declined quickly. The activity concentrated on one or very few craters and faded out in 5-8 days. The last eruption (September 4-18, 1984) was an exception. The first few days it behaved like the previous eruptions, but after the activity had been limited to one crater the vigor of the eruption began to increase. This increase continued until the $14^{\text {th }}$ day of the eruption when it suddenly ended.

\section{Inflation, 1984-1989}

The Krafla volcano began inflating again when the eruption of September 1984 was over. The inflation continued intermittently for several years, until 1989. The inflation was accompanied by a persistent background of small earthquakes, rarely exceeding magnitude 2, showing heterogeneous stress, with horizontal shear, extensional and compressional sources in close juxtaposition. A part of these events had sources with a large non-double couple component (Foulger et al., 1989). By 1989, the inflation had exceeded the level reached before the 1984 eruption (Sturkell et al., 2008). Since then, a slow deflation has been the main characteristic of the crustal deformation of the volcano, most likely reflecting gradual cooling of the caldera crustal volume and harnessing of the geothermal system (Drouin et al., 2017b). The seismicity of Krafla during this phase of slow deflation has been low, similar to that of other central volcanoes of the zone with a geothermal system, Peistareykir, Fremrinámar and Askja, with a couple of events per year of magnitude 2 and larger.

\section{General Pattern}

The course of events was governed by magma chamber inflation that continued for at least 15 years (Figure 2), interrupted by about 20 short deflation events when magma escaped from the holding chamber in the middle of the caldera and formed a dike that propagated along the fissure swarms, either to the north, the south, or both (Table 1) (Buck et al., 2006; Wright et al., 2012). These events were of variable magnitude, even though the deformation pattern in the caldera was the same. The shape of the deformation indicates a depth to the pressure source of about $3 \mathrm{~km}$ (Johnsen et al., 1980; Tryggvason, 1980). Thus, since the shape of the deformation field was unchanged, the relative size of the deflation events may be quantified by the total vertical displacement in the center of deflation that coincided with the center of the caldera and scales linearly with the volume of the deflation. The central maximum subsidence ranged between 3 and $203 \mathrm{~cm}$ (Table 1). Similarly, the final length of the dike that was formed in the fissure swarms ranged between a few 
$\mathrm{km}$ and $60 \mathrm{~km}$ (Figure 2). The seismicity changed dramatically during these deflation events. The caldera seismicity stopped instantaneously when the deflation began (Figure 3). Then, a flurry of events began near the caldera, propagating outward along the fissure swarm (Hjartardóttir et al., 2012). The speed of propagation was high in the beginning but slowed down as the distance from the caldera increased, see Figure 5 (Einarsson and Brandsdóttir, 1980). The rate of deflation followed the same pattern, was high in the beginning and then slowing down. The magnitude of the fissure swarm earthquakes increased as the swarm progressed and formed a cluster in a particular part of the fissure swarm, where large scale surface rifting was also observed in the largest events. The maximum speed of propagation was quite variable between deflation events, ranging between 0.2 and $1.8 \mathrm{~m} / \mathrm{s}$ (Table 1). The duration of the deflation events was also quite variable, between one day and three months.

The dikes reached the surface in nine of the cases, producing eruptions of basaltic lava from fissures of variable length, up to $9 \mathrm{~km}$ (Saemundsson, 1991). The first three eruptions were tiny, almost like geological accidents. The fourth eruption was slightly larger but of short duration. The volume of all these four eruptions was only a very small fraction of the volume of the dike or the deflation bowl. A new stage was reached with the eruption in July 1980. Then, most of the mobilized magma appears to have reached the surface. A good fraction of it flowed back into open fissures, however, and caused secondary rifting. The fissure that received the lava dilated and extended in both directions. Apparently, a dike was formed, fed from the surface, a phenomenon observed here for the first time. The flow into the fissures lasted at least $18 \mathrm{~h}$, and for several of those hours, the whole lava production went this way. Subsequent dikes also led to eruptions. The largest one was the last event in this remarkable sequence. All the eruptions except the first one were anticipated or predicted based on the combination of deformation and seismicity, and the warnings were issued to the local population before them (Einarsson, 2018).

During injection of dikes outside the caldera the deflation of the caldera was generally accompanied by very low caldera seismicity, sometimes with almost no detectable caldera earthquakes. Only in the two largest deflation events was there a detectable increase in the caldera seismicity. Earthquakes as large as $\mathrm{m}_{b} 5$ occurred during the first deflation event (Einarsson, 1986), and a slight increase in small earthquakes was detected toward the end of the deflation event of January 1978. Deflation at the caldera center was $2 \mathrm{~m}$ and $1 \mathrm{~m}$, respectively, in these events (Table 1). Deflation of less than $1 \mathrm{~m}$ apparently took place within the elastic range of the caldera floor. Dikes intruded within the caldera were clearly accompanied by seismicity during their propagation. Caldera earthquakes during inflation were significantly smaller than during deflation. They only rarely reached magnitude 4 .

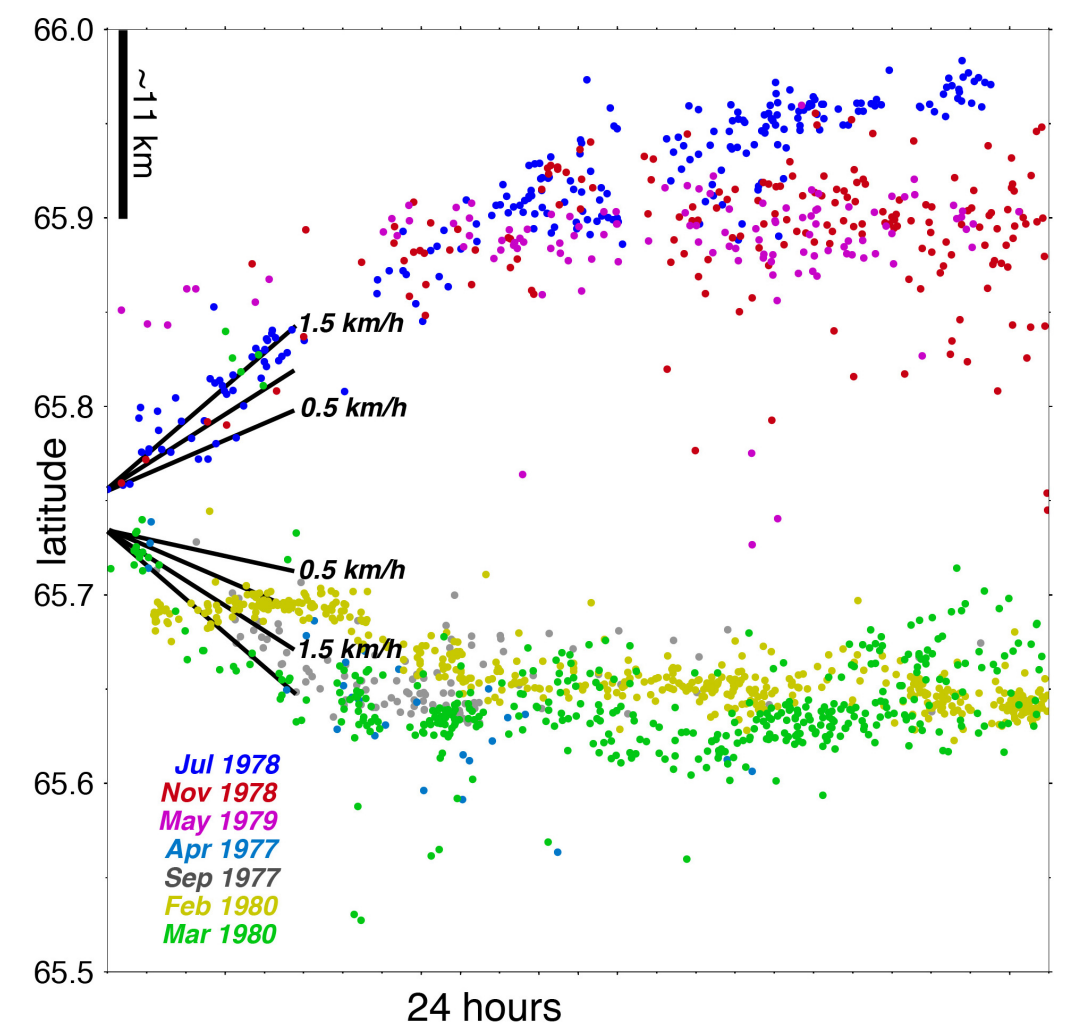

FIGURE 5 | Propagation of seismicity from the Krafla caldera during the swarms of 1977-1980, see Figure 4. The latitude of the epicenters is plotted as function of time during the first $24 \mathrm{~h}$ of each swarm. 
Attempts to estimate the volume of magma transported from depth to the shallow crust give varying results. Hollingsworth et al. (2013) used digital elevation models derived from aerial and spy photographs to estimate a total volume of intruded dikes $0.9-1.7 \times 10^{9} \mathrm{~m}^{3}$. They also estimate a volume of erupted lava of $0.2-0.4 \times 10^{9} \mathrm{~m}^{3}$. Values in the range $0.25-0.35 \times 10^{9} \mathrm{~m}^{3}$ were estimated from the surface flows (e.g., Einarsson, 1991b, 2018; Saemundsson, 1991). Using the cumulative deflation of the caldera to estimate the total volume of dikes and flows gives $0.79-0.85 \times 10^{9} \mathrm{~m}^{3}$ (Harris et al., 2000).

\section{Askja}

The Askja volcanic system consists of a central volcano and fissure swarms extending to the north and south. The northern swarm extends all the way to the north coast. The extent of the southern swarm is more uncertain. It interfingers with the swarms of the Bárðarbunga volcano and disappears beneath the Vatnajökull glacier. The structure of the Askja volcano is dominated by at least four overlapping caldera structures (Saemundsson, 1982; Hjartardóttir et al., 2009). Seismic tomographic studies reveal bodies of anomalous $\mathrm{V}_{P} / \mathrm{V}_{S}$ ratios underlying the calderas at discrete levels as deep as $20 \mathrm{~km}$ (Greenfield et al., 2016). The most recent caldera was formed in 1874 and following years, after a major rifting episode with basaltic eruptions in the fissure swarm and a large silicic explosive eruption of the central volcano (e.g., Sigurdsson and Sparks, 1978; Brandsdóttir, 1992). The activity since then has been limited to the central volcano, most recently in 1961. Since about 1973, the main caldera has been slowly deflating. The cumulative subsidence of the caldera center is approaching 0.4 m (Tryggvason, 1989; Pagli et al., 2006; Sturkell et al., 2006; de Zeeuw-van Dalfsen et al., 2013). The cause of the subsidence is generally thought to be a combination of a cooling and contracting magma chamber at a divergent plate boundary.

The Askja area in general is moderately seismically active (Figures 1, 6), and only a part of the activity appears to

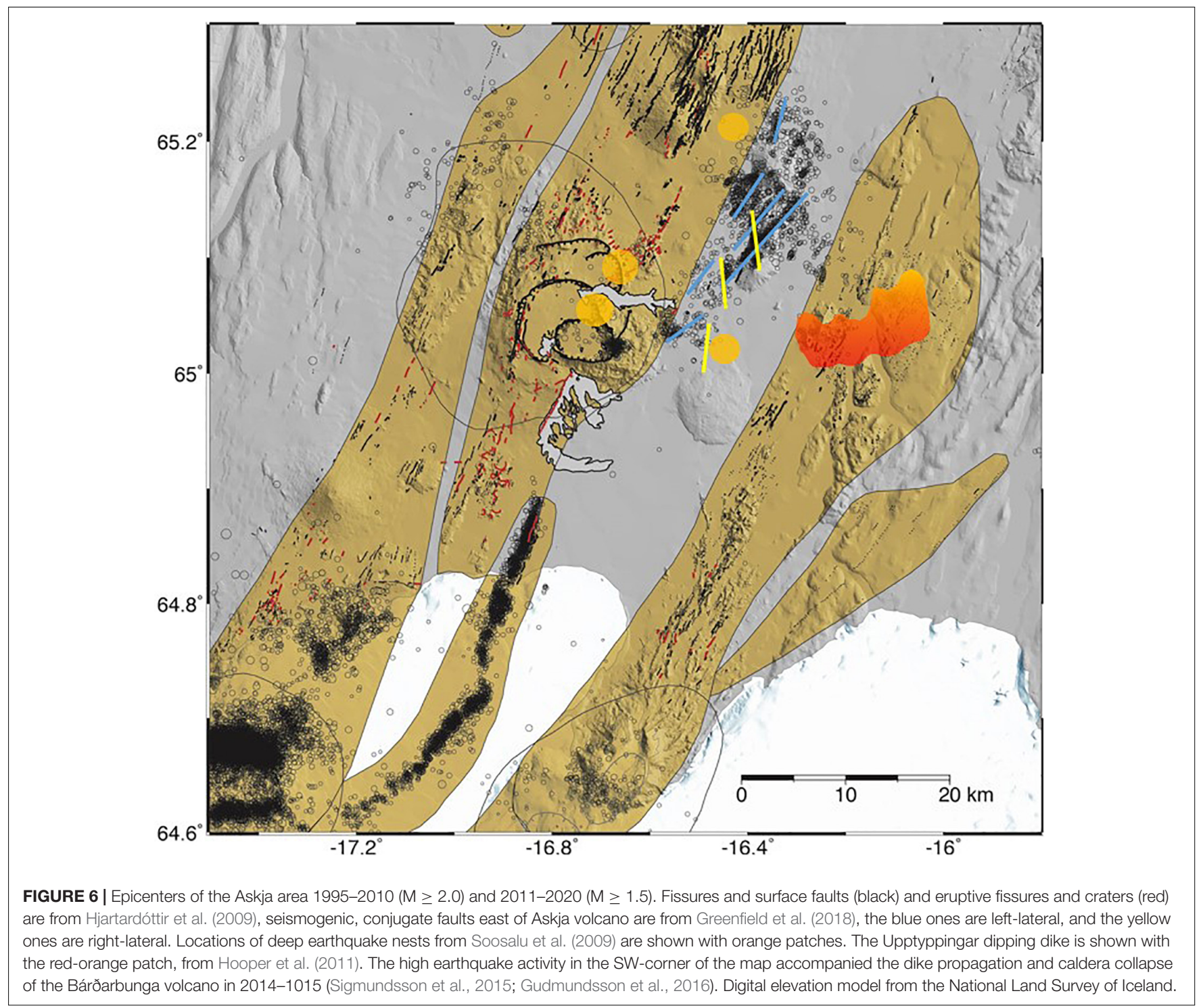


be related to the volcano itself (Einarsson, 1991a; Greenfield et al., 2018). Several processes have been suggested as sources of the different classes of earthquakes, including geothermal heat mining, transfer of spreading between overlapping fissure swarms, intrusion of a dike in the lower crust, and deep magma movements.

\section{Geothermal Heat Mining}

A persistent cluster of shallow level hypocenters is spatially correlated to the high-temperature geothermal field in the SE corner of the main caldera, suggesting a causal relationship between geothermal heat mining and brittle failure. This is also an area of silicic rock outcrops, and in 2014, this part of the caldera fault collapsed in a major rockslide, causing a large tsunami in the caldera lake (Gylfadóttir et al., 2017). Small swarms of shallow earthquakes occasionally occur in other parts of the caldera and to the $\mathrm{N}$ and $\mathrm{NW}$ of it. Most likely these events are related to the gentle deflation of the caldera.

\section{Transfer of Spreading Between the Askja and Kverkfjöll Fissure Swarms}

A large majority of the seismicity in the Askja area occurs east of Askja and appears to have no direct connection to the volcano. This activity was first described by Einarsson and Saemundsson (1987) and Einarsson (1991a). One NE-striking seismogenic fault was defined by the epicentral distribution, highly oblique to the fissure swarms nearby. Fault plane solutions showed strike-slip faulting (Jakobsdóttir, 2008). More detailed work using a dense temporary network by Soosalu et al. (2009) and Green et al. (2014) revealed more active faults in the area. Relative locations of numerous events show a system of conjugate faults bridging the gap between the fissure swarms of Askja and Kverkfjöll (Greenfield et al., 2018), NE-striking faults with left-lateral strike slip on them, and N-striking faults of rightlateral faulting (Figure 6). None of these faults are visible at the surface. The conjugate faults suggest a causative stress field with the least compressive principal stress in a WNW-ESE direction, consistent with the direction of plate spreading. The depth of the hypocenters is less than $8 \mathrm{~km}$, well within the brittle part of the crust. This activity therefore appears to be caused by transfer of spreading between the two overlapping fissure swarms.

\section{Upptyppingar Lower Crustal Intrusion}

An unusual sequence of small earthquakes was detected in the Northern Volcanic Zone, near the hyaloclastite mountain Upptyppingar east of the Askja volcano, beginning in February 2007 (Figure 6). The events were ordinary in appearance, but originated at unusually large depth, 10-20 km. The swarm was very persistent and spread out along a planar structure (Jakobsdóttir, 2008; White et al., 2011; Horálek et al., 2015) beginning at depth and then spreading upwards and eastwards. After a year the activity faded away and stopped. The swarm was accompanied by uplift of a large area. Modeling of the surface deformation revealed a planar intrusion with a strike of $80^{\circ} \mathrm{E}$ and dip of $45^{\circ}$ to $49^{\circ}$ coinciding with the planar structure outline by the hypocentral distribution (Martens et al., 2010). The volume was $(42-47) \times 10^{6} \mathrm{~m}^{3}$ (Hooper et al., 2011).
The intrusion is located within the Kverkfjöll fissure swarm (Figures 1, 6), about $40 \mathrm{~km}$ north of the Kverkfjöll central volcano. No deflation was detected of the Kverkfjöll central volcano in association with this intrusion, nor was the Askja volcano affected, the nearest neighboring central volcano. Apparently, the intrusion was fed directly from below. It is noteworthy that the orientation of the dike plane does not conform to any known structure at the surface. Fracture orientations are generally consistent with the stress field at a divergent plate boundary with the least compressive principal stress in the direction of relative plate motion (Hjartardóttir and Einarsson, 2012). Hooper et al. (2011) suggested that the stress field implied by the dike intrusion was modified by the presently ongoing retreat of the ice caps in Iceland, leading to enhanced capture of magma within the crust.

\section{Abnormally "Deep" Swarms}

A special class of abnormally deep earthquakes was first identified and described by Soosalu et al. (2009) in the area within and around the Askja volcano. These events originate in the depth range 10-34 km, i.e., well below the brittle-ductile transition. They are typically small, $\mathrm{M}<2$, and occur in dense and shortlived swarms of a few minutes' duration. The rapid succession of the events within a swarm may sometimes give the swarm the appearance of a tremor burst. The sources are quite persistent, on a time scale of years (Greenfield et al., 2018). Four nests of deep events have been located in the Askja area, two in the area of the central volcano, one about $10 \mathrm{~km}$ east of the volcano and one about $15 \mathrm{~km} \mathrm{NNE}$ of the volcano (Figure 6). Key et al. (2011) suggested that these events represent magmatic injections along the fissure swarm of Askja, and Greenfield and White (2015) suggested that they represent magma transport through the lower crust.

\section{DISCUSSION}

\section{Lateral Diking}

The observations at Krafla of propagating earthquakes away from the central volcano and into the fissure swarms on either side of the volcano, accompanied by deflation of the caldera and extensive rifting in the fissure swarms, were interpreted as a consequence of dikes propagating laterally from a magma chamber within the caldera and into the rift zone (e.g., Björnsson et al., 1977; Einarsson and Brandsdóttir, 1980; Tryggvason, 1980). The interpretation was inspired by similar events at Kilauea volcano in Hawaii (e.g., Fiske and Jackson, 1972), despite differences in tectonic setting. The horizontal extensional stress, providing the conditions for lateral propagation, was generated by plate divergence in Iceland but by gravitational sliding of the flank of Kilauea in Hawaii. There was no general consensus about this interpretation, however. Alternative interpretations were proposed (e.g., Gudmundsson, 1995). Cases of lateral diking accompanied by deflation of a magma storage or even collapse of a caldera have been documented since the Krafla activity began. These include the Piton de la Fournaise in 2007 (Staudacher et al., 2009), Miyakejima in 2000 (Geshi et al., 2002), Asal rifting 
of 1978, Dabbahu in Afar 2005-2010 (Wright et al., 2012), Bárðarbunga in Iceland in 2014-2015 (Sigmundsson et al., 2015; Gudmundsson et al., 2016), and Kilauea, Hawaii 2018 (Neal et al., 2019). Lateral draining of magma reservoirs is an important mechanism to form collapse calderas, involving processes like external tectonic stress, magma density and buoyancy in the crust, magma viscosity, and viscoelasticity in the crust (Buck et al., 2006; Sigmundsson et al., 2020).

\section{Magmatic and Non-magmatic Rifting}

One of the remarkable features of the Icelandic plate boundary rift zones is their highly variable seismicity, even on a time scale of decades. The rifting segment of the Eastern Volcanic Zone is, for example, almost totally aseismic, and so are segments of the Northern Volcanic Zone. Yet the relative plate divergence rate across these zones is $15-20 \mathrm{~mm} /$ year. Other parts of the divergent plate boundary, such as the segments of the Western Volcanic Zone, are moderately seismically active despite much lower spreading rate. Hjartardóttir et al. (2016a,b) suggested that this discrepancy was the result of cyclic activity. The deviatoric stress in a rift zone immediately following a rifting episode is low and the deformation due to plate spreading occurs within the elastic limit of the crust. The seismicity will be very low. With increasing stress, the deformation will gradually lead to failure and the background seismicity will increase. If magma becomes available, the failure limit of the crust is lowered and rifting may ensue even if the background seismicity is still low (Sigmundsson, 2006; Acocella and Trippanera, 2016). This was the case before the Krafla rifting episode in the early seventies. If, on the other hand, magma is not available, the stress may increase to the dry failure limit of the crust and failure takes place by normal faulting without the help of magma, as seems to be the case in a segment of the WVZ. This may be the explanation for the different level of seismicity in different segments of the Northern Volcanic Zone, evident in Figure 1. The recent large rifting episode of the Askja system in 1874-1875 relieved stress in the central part of the zone and the stress has not yet built up to seismogenic levels.

\section{Faulting Between Overlapping Rifting Structures}

Rifting in the rift zones of Iceland occurs within fissure swarms, apparently mostly by diking during rifting episodes. Modern examples of this type of activity include the Krafla rifting episode of 1975-1984 and the Bárðarbunga dike of 2014 (Sigmundsson et al., 2015; Gudmundsson et al., 2016). Each rift zone includes several fissure swarms that are arranged within the zone parallel to each other or en-echelon. Each dike or rifting event may only affect a limited length of one fissure swarm. This leads to accumulated horizontal shear stress between adjacent fissure swarms that is released in some kind of transfer motion on sets of conjugate strike-slip faulting. Two examples of such tectonism exist in the Icelandic rifts, the persistent seismicity east of the Askja volcano in the Northern Volcanic Zone, and the seismic activity in the Reykjanes Peninsula Oblique Rift (Hjaltadóttir, 2009; Parameswaran et al., 2020). In both areas, the orientation of the inferred least principal stress is horizontal and in the general direction of plate spreading.

\section{"Deep" Crustal and Upper Mantle Earthquakes}

Majority of earthquakes in Iceland originate in the upper, brittle part of the crust, in the depth range $0-10 \mathrm{~km}$, and are apparently linked with relative plate movements across the plate boundaries. There are, however, occasional deeper earthquakes, originating in material that would, at normal strain rates, deform in a ductile way under the pressure and temperature conditions corresponding to the depth. Two classes of deep earthquakes may be identified: (1) earthquake sequences occurring immediately preceding or during eruptions and (2) small events occurring in short-lived swarms in persistently active "nests" beneath some parts of the volcanic zones.

Examples of the first class of deep events are provided by the Heimaey eruption of 1973 and the Eyjafjallajökull eruptions of 2010. Most earthquakes during the Heimaey eruption occurred at $15-25 \mathrm{~km}$ depth and most likely also the swarm of events immediately preceding the eruption (Björnsson and Einarsson, 1974; Einarsson, 1991a). The Eyjafjallajökull eruptions of 2010 were preceded by a series of shallow-level sill intrusions in 1994, 1999, 2009, and 2010 (Pedersen and Sigmundsson, 2004, 2006; Sigmundsson et al., 2010), and a period of anomalously deep earthquakes in 1996 (Dahm and Brandsdóttir, 1997; Hjaltadóttir et al., 2009). Some of the earthquakes during the eruptions also occurred at lower-crustal depths and were clearly related to the feeding channels of the eruptions (Tarasewicz et al., 2012a,b). The prolonged earthquake sequence during the Upptyppingar dipping dike intrusion of 2007-2008 may also be included in this class, although no eruption ensued.

The second class of deep events, first identified on the temporary Askja network by Soosalu et al. (2009) in the area around the Askja volcano, occur in short-lived swarms, of a few minutes' duration. In addition to the four nests of deep events located in the Askja area, at least three additional nests of deep swarms have been identified and are regularly recorded by the permanent network. The most active one of them is located 15$20 \mathrm{~km}$ ESE of Bárðarbunga volcano, slightly south of the dike that propagated laterally from the volcano in August 2014 and fed the Holuhraun eruption (Sigmundsson et al., 2015). The relationship of this nest to the dike and the plumbing of the Bárðarbunga volcanic system is still unclear (Hudson et al., 2017). Several swarms per month are detected in this nest at the present time and the activity is not decreasing. Another nest with a spatial relationship to the Bárðarbunga system is located beneath the Trölladyngja lava shield, within the NE-fissure swarm of Bárðarbunga. Only one deep nest is yet known in South Iceland. It is located beneath the eastern rim and flank of the Katla volcano (Vogfjörð et al., 2009).

The detection of the deep nests depends critically on the seismic network. A seismic station in the nearfield of the earthquakes is required for sufficient depth control on the location of the events. It is rather likely that more of these nests will be identified in the future. The known nests are all, 
except one, located in the central area of the Iceland Hotspot. Some parts of the plate boundary areas seem to be devoid of deep nests. None have been found in the Reykjanes Peninsula Oblique Rift or in the Krafla volcanic system despite relatively dense networks in operation there. The deep swarms in Iceland show great similarity with recently discovered events in the Eifel volcanic field in Germany (Hensch et al., 2019; Dahm et al., 2020).

\section{Stages Within Eruptive Cycle}

A majority of the eruptions of Icelandic volcanoes within the last several decades occurred after a time of inflation of the respective volcano (Einarsson, 2018; Sigmundsson et al., 2018). The eruption is then accompanied by deflation and followed by repeated inflation. This includes the nine Krafla eruptions of 1975-1984, the three eruptions of Grímsvötn 1998-2011, and the three eruptions of Hekla 1980-2000. In the cases of Krafla and Grímsvötn, the seismicity follows the cyclic behavior; it increases during the inflation part of the cycle and is greatly reduced when the deflation sets in. If a dike propagates away from the inflated area, its propagation can often be traced by the earthquakes that are generated around the dike tip. The re-inflation is accompanied by little seismicity during its first stage. It may increase rather suddenly if the inflation level exceeds the previous maximum, a phenomenon called Kaiser effect (Heimisson et al., 2015). The deflation itself takes place almost aseismically as long as the strain remains within the elastic limits. In the case of Krafla, the elastic limit was exceeded only twice. The first deflation was about $2 \mathrm{~m}$ and was accompanied by considerable seismicity, with maximum magnitude 5.0. The second case was the January 1978 deflation (Table 1) when the subsidence in the caldera reached $1 \mathrm{~m}$. There was a slight increase of the daily number of small caldera earthquakes during the last days of deflation. Based on these observations, it may be concluded that the elastic range of the Krafla caldera is about $1 \mathrm{~m}$. Earthquakes associated with the inflation part of the cycle only reached magnitude 3.5 .

Similar behavior is observed in Grímsvötn. The seismic activity of the volcano is generally very low but increases slowly in the latter half of the inflation period. The maximum magnitude does not exceed 3. The deflation has so far always been within the elastic limit.

The large Bárðarbunga $65 \mathrm{~m}$ deflation of 2014-2015 was accompanied by numerous earthquakes, more than 70 of which exceeded magnitude 5 (Gudmundsson et al., 2016). The caldera seismicity decreased greatly when the deflation stopped in February 2015. The volcano began inflating again after the eruption and deflation ended but the seismicity remained low until September 2015 (Sigmundsson et al., 2018). Then, both the earthquake frequency and the maximum magnitude increased and remained high for several years (Pálsson et al., 2019). The maximum magnitude exceeded 4 but has remained below 5 , however. All three volcanoes appear to have a similar seismic behavior with respect to inflation and deflation. Inflationrelated earthquakes are generally smaller than the earthquakes accompanying deflation.

\section{Geothermal Activity and Seismicity}

It has been noted in many publications that there is a general correlation between persistent microearthquake activity within the volcanic zones of Iceland and the high-temperature geothermal areas (e.g., Ward and Björnsson, 1971). It may be argued that temperature changes associated with geothermal systems and the transfer of heat from the heat source to the colder bodies of rock leads to stress changes and thus to micro-cracking in the brittle part of the crust. The non-double-couple part of the earthquake source mechanisms identified by Foulger (1988); Miller et al. (1998), and Schuler et al. (2016) in the Hengill and Krafla areas may be taken as evidence for this. This mechanism has also been suggested as one of the possible sources of the seismicity of the Katla and Askja calderas, Torfajökull volcano, and the subglacial Loki Ridge (Einarsson, 1991a; Soosalu and Einarsson, 1996, 1997; Sturkell et al., 2008; Sgattoni et al., 2019). It is rather unlikely, however, that all the background seismicity of these locations is due to the geothermal mining of heat. The case of the Kerlingarfjöll area within the Hofsjökull volcanic system serves as a counterexample. This central volcano has a very powerful geothermal system, and yet, the seismicity is very low. This case suggests that the geothermal effect is likely to act as a trigger rather than the main driving force of the seismicity. The Kerlingarfjöll volcano is located outside the main deformation zone of the plate boundary. The driving force may therefore be missing even though the trigger is there.

Elevated pressure in the pore fluid may be another mechanism to release rock stress in a geothermal system close to a volcano by lowering the effective stress on pre-stressed faults. The validity of this mechanism is demonstrated in cases where the pore pressure change is induced by man, e.g., at the Hellisheiði Geothermal Power Station in SW-Iceland, where seismicity and crustal deformation is induced by injection of wastewater into the crust (Juncu et al., 2020).

We point out that many of the high-temperature geothermal systems are spatially correlated with outcrops of silicic rocks. This raises the question whether shallow, unstable, low-density bodies of silicic rocks (cryptodomes) may be the source of both the geothermal activity and the earthquakes.

\section{CONCLUSION}

Seismicity serves as the most important element in the long-term monitoring of the $30+$ active volcanic systems of Iceland. About half of them have shown evidence of magma movements in the last 46 years of coverage by sensitive seismographs.

Processes identified as causes of earthquakes within the volcanic zones include volcano inflation and deflation, caldera collapse, dike and sill intrusion, amagmatic rifting by normal faulting, geothermal heat mining, strike-slip faulting on systems of conjugate faults, and unspecified movements of magma in the deep crust. Dome and cryptodome activity may also play a role.

Seismicity within the volcanically active areas of Iceland is very unevenly distributed, both in time and space. Persistent seismic sources are mostly associated with central volcanoes. The fissure swarms of the volcanic systems are usually inactive, even at the 
microearthquake level, except during rifting episodes when dikes propagate within them. The major rifting episode in the Krafla area 1975-1984 showed lateral injection of dikes, a model that was verified by the Bárðarbunga dike injection and rifting of 2014.

The long-term behavior of the different volcanic systems of the Northern Volcanic Zone is quite varied, ranging from very low-level background activity like Fremrinámar and Peistareykir, to almost continuous, intermediate-level seismicity, like that of the area around the Askja volcano. For successful monitoring it is therefore essential to have a long time-history of the seismicity. A part of the seismic activity east of Askja is generated by strike-slip faulting on conjugate fault sets, taking up differential strain between overlapping rift zones of adjacent volcanic systems.

The rifting events at Krafla in 1975-1984 occurred during a phase of cyclic behavior, with periods of magma accumulation at depth and inflation punctuated by deflation, dike intrusions, rifting and eruptions. The cycle of inflation and deflation was reflected in seismicity that provides an additional parameter to apply in the monitoring effort. The examples of this process so far suggest that the largest earthquakes during deflation are significantly larger than the inflation-related earthquakes of the same volcano.

Persistent activity of small earthquakes in all four volcanic systems appears to be spatially correlated with high-temperature hydrothermal systems. The causal relationship is not always obvious. Cooling of hot rock bodies and consequent contraction and associated stress change may provide part of the explanation, also pore pressure fluctuations within the geothermal system. It is also pointed out that both phenomena, seismicity and geothermal activity, in some cases could have a common cause, such as a rising cryptodome.

\section{REFERENCES}

Acocella, V., and Trippanera, D. (2016). How diking affects the tectonomagmatic evolution of slow spreading plate boundaries: overview and model. Geosphere 12, 867-883. doi: 10.1130/GES01271.1

Árnadóttir, T. H., Lund, B., Jiang, W., Geirsson, H., Björnsson, H., Einarsson, P., et al. (2009). Glacial rebound and plate spreading: results from the first countrywide GPS observations in Iceland. Geophys. J. Int. 177, 691-716. doi: 10.1111/j.1365-246X.2008.04059.x

Björnsson, A., and Eysteinsson, H. (1998). Breytingar á landhœð við Kröflu 1974-1995. Samantekt á landhøðarmolingum (Changes in Elevation at Krafla 1974-1995. Compilation of Elevation Measurements, in ICELANDIC). Reykjavík: Nordic Volcanological Institute. National Energy Authority, Report OS-98002, Report 9801.

Björnsson, A., Sæmundsson, K., Einarsson, P., Tryggvason, E., and Grönvold, K. (1977). Current rifting episode in north Iceland. Nature 266, 318-323. doi: $10.1038 / 266318 \mathrm{a} 0$

Björnsson, S., and Einarsson, P. (1974). "Seismicity of Iceland," in Geodynamics of Iceland and the North Atlantic Area, ed. L. Kristjánsson (Dordrecht: Reidel Publ. Co), 225-239. doi: 10.1007/978-94-010-2271-2_16

Brandsdóttir, B. (1992). Historical accounts of earthquakes associated with eruptive activity in the Askja volcanic system. Jökull 42, 1-12.

Brandsdóttir, B., and Einarsson, P. (1979). Seismic activity associated with the September 1977 deflation of the Krafla central volcano in NE-Iceland. J. Volc. Geotherm. Res. 6, 197-212. doi: 10.1016/0377-0273(79)90001-5

Brandsdóttir, B., and Menke, W. H. (1992). Thin low-velocity zone within the Krafla caldera, NE-Iceland attributed to a small magma chamber. Geophys. Res. Lett. 19, 2381-2384. doi: 10.1029/92gl02541

\section{DATA AVAILABILITY STATEMENT}

The raw data supporting the conclusions of this article will be made available by the authors, without undue reservation.

\section{AUTHOR CONTRIBUTIONS}

Both authors contributed equally to the subject of the study. PE with emphasis on the text and $\mathrm{BB}$ with emphasis on data analysis and construction of the figures. Both authors have worked for several decades on seismic monitoring and tectonics of Iceland and were actively involved in the seismic monitoring of the Krafla rifting episode.

\section{ACKNOWLEDGMENTS}

This study is based on data and active cooperation of many people and institutions, including the Lamont-Doherty Earth Observatory and Cambridge University. The monitoring effort during the Krafla rifting episode relied to a large extent on the work of devoted local attendants of the analog seismograph system. The seismic data since 1990 are obtained from the Icelandic Meteorological Office. Seismic monitoring in the Northern Volcanic Zone has been partly supported by Landsvirkjun, the National Power Company of Iceland. The Generic Mapping Tools software (Wessel et al., 2019) was used to generate most of the Figures. Comments from the Editor and two reviewers improved the study considerably.

Buck, W. R., Einarsson, P., and Brandsdóttir, B. (2006). Tectonic stress and magma chamber size as controls on dike propagation: constraints from the 1975-1984 Krafla rifting episode. J. Geophys. Res. 111:B124041.

Dahm, T., and Brandsdóttir, B. (1997). Moment tensors of microearthquakes from the Eyjafjallajökull volcano in South Iceland. Geophys. J. Int. 130, 183-192. doi: 10.1111/j.1365-246x.1997.tb00997.x

Dahm, T., Stiller, M., Mechie, J., Heimann, S., Hensch, M., Woith, H., et al. (2020). Seismological and geophysical signatures of the deep crustal magma systems of the Cenozoic volcanic fields beneath the Eifel, Germany. $G^{3}$ 21:e2020GC009062. doi: 10.1029/2020GC009062

de Zeeuw-van Dalfsen, E., Rymer, H., Sturkell, E., Pedersen, R., Hooper, A., Sigmundsson, F., et al. (2013). Geodetic data shed light on ongoing caldera subsidence at Askja, Iceland. Bull. Volcanol. 75:709. doi: 10.1007/s00445-0130709-2

Drouin, V., Sigmundsson, F., Ófeigsson, B. G., Hreinsdóttir, S., Sturkell, E., and Einarsson, P. (2017a). Deformation in the Northern Volcanic Zone of Iceland 2008-2014: an interplay of tectonic, magmatic, and glacial isostatic deformation. J. Geophys. Res. Solid Earth 122, 3158-3178. doi: 10.1002/2016JB013206

Drouin, V., Sigmundsson, F., Verhagen, S., Ófeigsson, B. G., Spaans, K., and Hreinsdóttir, S. (2017b). Deformation at Krafla and Bjarnarflag geothermal areas, Northern Volcanic Zone of Iceland, 1993-2015. J. Volcan. Geotherm. Res. 344, 92-105. doi: 10.1016/j.jvolgeores.2017.06.013

Einarsson, P. (1978). S-wave shadows in the Krafla caldera in NE-Iceland, evidence for a magma chamber in the crust. Bull. Volc. 41, 1-9.

Einarsson, P. (1986). "Seismicity along the eastern margin of the North American Plate," in The Western North Atlantic Region: Geological Society of America, eds P. R. Vogt and B. E. Tucholke (Boulder, CO: The Geology of North America), 99-116. doi: 10.1130/dnag-gna-m.99 
Einarsson, P. (1987). "Compilation of earthquake fault plane solutions in the North Atlantic and Arctic Oceans," in Recent Plate Movements and Deformation, Geodynamics Series, Vol. 20, ed. K. Kasahara (Washington, DC: America Geophysical Union), 47-62. doi: 10.1029/gd020p0047

Einarsson, P. (1991a). Earthquakes and present-day tectonism in Iceland. Tectonophysics 189, 261-279. doi: 10.1016/0040-1951(91)90501-i

Einarsson, P. (1991b). “The Krafla rifting episode 1975-1989," in Náttúra Mývatns, eds A. Garðarsson and A. Einarsson (Reykjavík: Icelandic Nature Science Society), 97-139. doi: 10.1016/0377-0273(84)90036-2

Einarsson, P. (2008). Plate boundaries, rifts and transforms in Iceland. Jökull 58, 35-58.

Einarsson, P. (2018). Short-term seismic precursors to Icelandic eruptions $1973-$ 2014. Front. Earth Sci. Volcanol. Res. Topic 6:45. doi: 10.3389/feart.2018. 00045

Einarsson, P., and Brandsdóttir, B. (1980). Seismological evidence for lateral magma intrusion during the July 1978 deflation of the Krafla volcano in NE-Iceland. J. Geophys. 47, 160-165.

Einarsson, P., and Jakobsson, S. (2020). Scanning the analog seismogram archives of Iceland. Jökull 70:16. doi: 10.33799/jokull2020

Einarsson, P., and Saemundsson, K. (1987). "Earthquake epicentres 1982-1985 and volcanic systems in Iceland: A map," in Í hlutarins eðli, Festschrift for Porbjörn Sigurgeirsson, ed. P. Sigfússon (Reykjavík: Menningarsjóður).

Fiske, R. S., and Jackson, E. D. (1972). Orientation and growth of Hawaiian volcanic rifts: the effect of regional structure and gravitational stresses. Proc. R. Soc. Lond. 329, 299-326. doi: 10.1098/rspa.1972.0115

Foulger, G. R. (1988). Hengill triple junction, SW Iceland; 2. Anomalous earthquake focal mechanisms and implications for process within the geothermal reservoir and at accretionary plate boundaries. J. Geophys. Res. 93, 507-523.

Foulger, G. R., Long, R. E., Einarsson, P., and Björnsson, A. (1989). Implosive earthquakes at the active accretionary plate boundary, Northern Iceland. Nature 337, 640-642. doi: 10.1038/337640a0

Geshi, N., Shimano, T., Chiba, S., and Nakada, S. (2002). Caldera collapse during the 2000 eruption of Miyakejima Volcano. Jpn. Bull. Volcanol. 64, 55-68. doi: 10.1007/s00445-001-0184-z

Green, R. G., Greenfield, T., and White, R. S. (2015). Triggered earthquakes suppressed by an evolving stress shadow from a propagating dyke. Nat. Geosci. 8, 629-632. doi: 10.1038/ngeo2491

Green, R. G., White, R. S., and Greenfield, T. (2014). Motion in the north Iceland volcanic rift zone accommodated by bookshelf faulting. Nat. Geosci. 7, 29-33. doi: 10.1038/ngeo2012

Greenfield, T., and White, R. S. (2015). Building icelandic ignieous crust by repeated melt injections. J. Geophys. Res. 120, 1-14. doi: 10.1016/j.tecto.2007. 11.024

Greenfield, T., White, R. S., and Roecker, S. (2016). The magmatic plumbing system of the Askja central volcano, Iceland, as imaged by seismic tomography. J. Geophys. Res. Solid Earth 121, 7211-7229. doi: 10.1002/2016JB013163

Greenfield, T., White, R. S., Winder, T., and Ágústsdóttir, T. H. (2018). Seismicity of the Askja and Bárðarbunga volcanic systems of Iceland, 2009-2015. J. Volcanol. Geotherm. Res. 391, 106432. doi: 10.1016/j.jvolgeores.2018.08.010

Gudmundsson, A. (1995). Infrastructure and mechanics of volcanic systems in Iceland. J. Volcanol. Geotherm. Res. 64, 1-22. doi: 10.1016/0377-0273(95) 92782-q

Gudmundsson, M. T., Jónsdóttir, K., Hooper, A., Holohan, E. P., Halldórsson, S. A., Ófeigsson, B. G., et al. (2016). Gradual caldera collapse at Bárdarbunga volcano, Iceland, regulated by lateral magma outflow. Science 353:aaf8988. doi: 10.1126/science.aaf 8988

Gylfadóttir, S. S., Kim, J., Helgason, J. K., Brynjólfsson, S., Höskuldsson, Á, Jóhannesson, T., et al. (2017). The 2014 Lake Askja rockslide-induced tsunami: Optimization of numerical tsunami model using observed data. J. Geophys. Res. Oceans 122:496. doi: 10.1002/2016JC012496

Harris, A., Murray, J., Aries, S., Davies, M., Flynn, L., Wooster, M., et al. (2000). Effusion rate trends at Etna and Krafla and their implications for eruptive mechanisms. J. Volcanol. Geotherm. Res. 102, 237-270. doi: 10.1016/s03770273(00)00190-6

Heimisson, E. R., Einarsson, P., Sigmundsson, F., and Brandsdóttir, B. (2015). Kilometer- scale Kaiser effect identified in Krafla volcano, Iceland. Geophys. Res Lett. 42, 7958-7965. doi: 10.1002/2015GL065680
Hensch, M., Dahm, T., Ritter, J., Heimann, S., Schmidt, B., Stange, S., et al. (2019). Deep low-frequency earthquakes reveal ongoing magmatic recharge beneath Laacher See Volcano (Eifel, Germany). Geophys. J. Int. 216, 2025-2036. doi: 10.1093/gji/ggy532

Hjaltadóttir, S. (2009). Use of Relatively Located Microearthquakes to Map Fault Patterns and Estimate the Thickness of the Brittle Crust in Southwest Iceland. M. Sc. thesis, University of Iceland, Reykjavík. Available online at: https:// skemman.is/bitstream/1946/3990/1/Sigurlaug-MS- fixed.pdf

Hjaltadóttir, S., Vogfjörð, K., and Slunga, R. (2009). Seismic signs of magma pathways Through the Crust in the Eyjafjallajökull Volcano, South Iceland. Icelandic Meteorological Office, Report VÍ 2009-013, 3. Available online at: https: //www.vedur.is/media/vedurstofan/utgafa/skyrslur/2009/VI_2009_013.pdf

Hjartardóttir, ÁR., and Einarsson, P. (2012). The Kverkfjöll fissure swarm and the eastern boundary of the Northern Volcanic Rift Zone, Iceland. Bull. Volcanol. 74, 143-162. doi: 10.1007/s00445-011-0496-6

Hjartardóttir, ÁR., Einarsson, P., Bramham, E., and Wright, T. J. (2012). The Krafla fissure swarm, Iceland, and its formation by rifting events. Bull. Volcanol. 74, 2139-2153. doi: 10.1007/s00445-012-0659-0

Hjartardóttir, ÁR., Einarsson, P., Magnúsdóttir, S., Björnsdóttir, P, and Brandsdóttir, B. (2016a). "Fracture systems of the Northern Volcanic Rift Zone, Iceland - An onshore part of the Mid-Atlantic plate boundary," in Magmatic Rifting and Active Volcanism, eds T. J. Wright, A. Ayele, D. J. Ferguson, T. Kidane, and C. Vye-Brown (London: Geological Society), 420. doi: $10.1144 /$ SP420.1

Hjartardóttir, Á. R., Einarsson, P., and Björnsdóttir, S. G. (2016b). Fissure swarms and fracture systems within the Western Volcanic Zone, Iceland - effects of spreading rates. J. Struct. Geol. 91, 39-53, doi: 10.1016/j.jsg.2016.08.007

Hjartardóttir, ÁR., Einarsson, P., and Sigurðsson, H. (2009). The fissure swarm of the Askja volcanic system along the divergent plate boundary of N Iceland. Bull. Volc. 71, 961-975. doi: 10.1007/s00445-009-0282-x

Hollingsworth, J., Leprince, S., Ayoub, F., and Avouac, J. P. (2013). New constraints on dike injection and fault slip during the 1975-1984 Krafla rift crisis, NE Iceland. J. Geophys. Res.: Solid Earth 118, 3707-3727. doi: 10.1002/jgrb.50223

Hooper, A., Ofeigsson, B. G., Sigmundsson, F., Lund, B., Geirsson, H., Einarsson, P., et al. (2011). Increased capture of magma in the crust promoted by ice-cap retreat in Iceland. Nat. Geosci. 4, 783-786. doi: 10.1038/NGEO1269

Horálek, J., Fischer, T., Einarsson, P., and Jakobsdóttir, S. S. (2015). "Earthquake swarms," in Encyclopedia of Earthquake Engineering, eds M. Beer, E. Patelli, I. A. Kougioumtzoglou, and S.-K. Au (Berlin: Springer), doi: 10.1007/978-3642-36197-5_294-1

Hudson, T. S., White, R. S., Greenfield, T., Ágústsdóttir, T. H., Brisbourne, A., and Green, R. G. (2017). Deep crustal melt plumbing of Bárðarbunga volcano, Iceland. Geophys. Res. Lett. 44, 8785-8794. doi: 10.1002/2017GL074749

Jakobsdóttir, S. (2008). Seismicity in Iceland: 1994-2007. Jökull 58, 75-100.

Johnsen, G., Björnsson, A., and Sigurðsson, S. (1980). Gravity and elevation changes caused by magma movement beneath the Krafla caldera, Northeast Iceland. J. Geophys. 47, 132-140.

Juncu, D., Árnadóttir, T., Geirsson, H., Guðmundsson, G. B., Lund, B., Gunnarsson, G., et al. (2020). Injection-induced surface deformation and seismicity at the Hellisheidi geothermal field, Iceland. J. Volc. Geotherm. Res. 391:106337. doi: 10.1016/j.jvolgeores.2018.03.019

Key, J., White, R. S., Soosalu, H., and Jakobsdóttir, S. S. (2011). Multiple melt injection along a spreading segment at Askja, Iceland. Geophys. Res. Lett. 38:L05301. doi: 10.1029/2010GL046264

La Femina, P. C., Dixon, T. H., Malservisi, R., Árnadóttir, T. H., Sturkell, E., Sigmundsson, F., et al. (2005). Geodetic GPS measurements in south Iceland: strain accumulation and partitioning in a propagating ridge system. J. Geophys. Res. 110:B11405. doi: 10.1029/2005JB003675

Lahr, J. J. C., and Ward, P. L. (1976). Hypoellipse: A Computer Program for Determining Local Hypocentral Parameters, Magnitude and First Motion Pattern. Reston, VA: U. S. Geological Survey. U. S. Geological Survey Open File Report.

Larsen, G., Grönvold, K., and Thorarinsson, S. (1979). Volcanic eruption through a geothermal borehole at Námafjall, Iceland. Nature 278, 707-710. doi: 10.1038/ $278707 \mathrm{a} 0$

Martens, H. R., White, R. S., Key, J., Drew, J., Soosalu, H., and Jakobsdóttir, S. S. (2010). Dense seismic network provides new insight into the 2007 Upptyppingar dyke intrusion. Jökull 60, 47-66. 
Miller, A. D., Julian, B. R., and Foulger, G. R. (1998). Three-dimensional seismic structure and moment tensors of non-double-couple earthquakes at the Hengill-Grensdalur volcanic complex, Iceland. Geophys. J. Int. 133, 309-325. doi: 10.1046/j.1365-246x.1998.00492.x

Neal, C. A., Brantley, S. R., Antolik, L., Babb, J. L., Burgess, M., Calles, K., et al. (2019). The 2018 rift eruption and summit collapse of Kilauea Volcano. Science 363, 367-374. doi: 10.1126/science.aav7046

Pagli, C. F., Sigmundsson, L., Árnadóttir, T., Einarsson, P., and Sturkell, E. (2006). Deflation of the Askja volcanic system: constraints on the deformation source from combined inversion of satellite radar interferograms and GPS measurements. J. Volc. Geotherm. Res. 152, 97-108. doi: 10.1016/j.jvolgeores. 2005.09.014

Pálmason, G. (1963). Seismic refraction investigation of the basalt lavas in northern and eastern Iceland. Jökull 13, 40-60.

Pálsson, M., Einarsson, P., and Hrafnkelsson, B. (2019). Variation in b-value of caldera earthquakes during recent activity of the Bárðarbunga volcano in Iceland. Jökull 69, 71-82. doi: 10.33799/jokull2019.69.071

Parameswaran, R. M., Thorbjarnardóttir, B. S., Stefánsson, R., and Bjarnason, I. T. H. (2020). Seismicity on conjugate faults in Ölfus, South Iceland: case study of the 1998 Hjalli-Ölfus earthquake. J. Geophys. Res. Solid Earth 125:e2019JB019203. doi: 10.1029/2019JB019203

Passarelli, L., Maccaferri, F., Rivalta, E., Dahm, T., and Boku, E. A. (2013). A probabilistic approach for the classification of earthquakes as 'triggered'or 'not triggered'. J. Seismol. 17, 165-187. doi: 10.1007/s10950-012-9289-4

Pedersen, R., and Sigmundsson, F. (2004). InSAR based sill model links spatially offset areas of deformation and seismicity for the 1994 unrest episode at Eyjafjallajökull volcano, Iceland. Geophys. Res. Lett. 31:L14610. doi: 10.1029/ 2004GL020368

Pedersen, R., and Sigmundsson, F. (2006). Temporal development of the 1999 intrusive episode in the Eyjafjallajökull volcano, Iceland, derived from InSAR images. Bull. Volcanol. 68, 377-393. doi: 10.1007/s00445-0050020-y

Pedersen, R., Sigmundsson, F., and Einarsson, P. (2007). Controlling factors on earthquake swarms associated with magmatic intrusions; constraints from Iceland. J. Volcanol. Geotherm. Res. 162, 73-80. doi: 10.1016/j.jvolgeores.2006. 12.010

Rooyakkers, S. M., Stix, J., Berlo, K., and Barker, S. J. (2020). Emplacement of unusual rhyolitic to basaltic ignimbrites during collapse of a basalt-dominated caldera: The Halarauður eruption, Krafla (Iceland). GSA Bull. 132, 1881-1902. doi: 10.1130/B35450.1

Schuler, J., Greenfield, T., White, R. S., Roecker, S. W., Brandsdóttir, B., Stock, J. M., et al. (2015). Seismic imaging of the shallow crust beneath the Krafla central volcano, NE Iceland. J. Geophys. Res. Solid Earth 120, 7156-7173. doi: 10.1002/2015JB012

Schuler, J., Pugh, D. J., Hauksson, E., White, R. S., Stock, J. M., and Brandsdóttir, B. (2016). Focal mechanisms and size distribution of earthquakes beneath the Krafla central volcano, NE Iceland. J. Geophys. Res. Solid Earth 121, 5152-5168. doi: 10.1002/2016jb013213

Sgattoni, G., Lucchi, F., Einarsson, P., De Astis, G., and Tranne, C. A. (2019). The 2011 unrest at Katla volcano: seismicity and geological context. Jökull 69, 53-70. doi: 10.33799/jokull2019.69.053

Sigmundsson, F. (2006). Iceland Geodynamics: Crustal Deformation and Divergent Plate Tectonics. Chichester: Springer-Praxis, 209.

Sigmundsson, F., Einarsson, P., Bilham, R., and Sturkell, E. (1995). Rift-transform kinematics in south Iceland: deformation from Global Positioning system measurements, 1986 to 1992. J. Geophys. Res. 100, 6235-6248. doi: 10.1029/ $95 \mathrm{jb} 00155$

Sigmundsson, F., Hooper, A., Hreinsdóttir, S., Vogfjörd, K. S., Ófeigsson, B. G., Heimisson, E. R., et al. (2015). Segmented lateral dyke growth in a rifting event at Bárðarbunga volcanic system, Iceland. Nature 517, 191-195. doi: 10.1038/ nature 14111

Sigmundsson, F., Hreinsdóttir, S., Hooper, A., Árnadóttir, T. H., Pedersen, R., Roberts, M. J., et al. (2010). Intrusion triggering of the 2010 Eyjafjallajökull explosive eruption. Nature 468, 426-430. doi: 10.1038/nature09558

Sigmundsson, F., Parks, M., Pedersen, R., Jónsdóttir, K., Ófeigsson, B. G., Grapenthin, R., et al. (2018). "Magma movements in volcano plumbing systems and their associated ground deformation and seismic pattern. Chapter 11," in Volcanic and Igneous Plumbing Systems, ed. S. Burchardt (Amsterdam: Elsevier), 285-322. doi: 10.1016/B978-0-12-809749-6.00011-X

Sigmundsson, F., Pinel, V., Grapenthin, R., Hooper, A., Halldórsson, S., Einarsson, P., et al. (2020). Unexpected large eruptions from buoyant magma bodies within viscoelastic crust. Nature Commun. 11:2403. doi: 10.1038/s41467-020-16054-6

Sigurdsson, H., and Sparks, S. R. J. (1978). Rifting episode in North Iceland in 18741875 and the eruptions of Askja and Sveinagja. Bull. Volcanol. 41, 149-167. doi: 10.1007/bf02597219

Sigurdsson, O. (1980). Surface deformation of the Krafla fissure swarm in two rifting events. J. Geophys. 47, 154-159.

Soosalu, H., and Einarsson, P. (1996). "Torfajökull seismicity - Hydrothermal cooling of a magma body?", in Seismology in Europe, ed. B. Thorkelsson (Reykjavík: European Seismological Commission), 467-472.

Soosalu, H., and Einarsson, P. (1997). Seismicity around the Hekla and Torfajökull volcanoes, Iceland, during a volcanically quiet period, 1991-1995. Bull. Volcanol. 59, 36-48. doi: 10.1007/s004450050173

Soosalu, H., Key, A. J., White, R. S., Knox, C., Einarsson, P., and Jakobsdóttir, S. S. (2009). Lower-crustal earthquakes caused by magma movement beneath Askja volcano on the north Iceland rift. Bull. Volcanol. 72, 55-62. doi: 10.1007/ s00445-009-0297-3

Staudacher, T., Ferrazzini, V., Peltier, A., Kowalski, P., Boissier, P., Catherine, P., et al. (2009). The April 2007 eruption and the Dolomieu crater collapse, two major events at Piton de la Fournaise (La Réunion Island, Indian Ocean). J. Volcanol. Geotherm. Res. 184, 126-137. doi: 10.1016/j.jvolgeores.2008. 11.005

Stefánsson, R., Böðvarsson, R., Slunga, R., Einarsson, P., Jakobsdóttir, S., Bungum, H., et al. (1993). Earthquake prediction research in the South Iceland seismic zone and the SIL project. Bull. Seismol. Soc. Am. 83, 696-716.

Sturkell, E., Einarsson, P., Sigmundsson, F., Geirsson, H., Pedersen, R., Van Dalfsen, E., et al. (2006). Volcano geodesy and magma dynamics in Iceland. J. Volc. Geotherm. Res. 150, 14-34. doi: 10.1016/j.jvolgeores.2005.07. 010

Sturkell, E., Sigmundsson, F., Geirsson, H., Ólafsson, H., and Theodórsson, T. (2008). Multiple volcano deformation sources in a post-rifting period: 1989-2005 behaviour of Krafla, Iceland constrained by levelling, tilt and GPS observations. J. Volcanol. Geotherm. Res. 177, 405-417. doi: 10.1016/j. jvolgeores.2008.06.013

Saemundsson, K. (1974). Evolution of the axial rifting zone in Northern Iceland and the Tjörnes fracture zone. Geol. Soc. Am. Bull. 85, 495-504. doi: 10.1130/ 0016-7606(1974)85<495:eotarz>2.0.co;2

Saemundsson, K. (1978). "Fissure swarms and central volcanoes of the neovolcanic zones in Iceland," in Crustal Evolution in Northwestern Britain and Adjacent Regions, Vol. 10, eds D. R. Bowes and B. E. Leake (Washington, DC: Geological Society), 415-432.

Saemundsson, K. (1982). "Calderas in the Neovolcanic zones of Iceland," in Eldur er í norðri (Fires in the North), Festschrift for Sigurður Pórarinsson, eds H. Pórarinsdóttir, Ó. H. Óskarsson, S. SteinPórsson, and P. Einarsson (Reykjavík: Sögufélag), 221-239.

Saemundsson, K. (1991). "Geology of the Krafla area," in Náttúra Mývatns, (The Nature of lake Mývatn), eds A. Gardarsson and A. Einarsson (Reykjavík: Icelandic Nature Science Society), 25-95.

Tarasewicz, J., Brandsdóttir, B., White, R. S., Hensch, M., and Thorbjarnardóttir, B. (2012a). Using microearthquakes to track repeated magma intrusions beneath the Eyjafjallajökull stratovolcano, Iceland. J. Geophys. Res. 117:B00C06. doi: 10.1029/2011JB008751

Tarasewicz, J., White, R. S., Woods, A. W., Brandsdóttir, B., and Gudmundsson, M. T. (2012b). Magma mobilization by downward-propagating decompression of the Eyjafjallajökull volcanic plumbing system. Geophys. Res. Lett. 39:L19309. doi: 10.1029/2012GL053518

Tryggvason, E. (1980). Subsidence events in the Krafla caldera, North Iceland, 1975-1979. J. Geophys. 47, 141-153.

Tryggvason, E. (1984). Widening of the Krafla fissure swarm during the 19751981 volcano-tectonic episode. Bull. Volcanol. 47, 47-69. doi: 10.1007/bf01960 540

Tryggvason, E. (1989). Ground deformation in Askja, Iceland: Its source and possible relation to flow of the mantle plume. J. Volcanol. Geotherm. Res. 39, 61-71. doi: 10.1016/0377-0273(89)90021-8 
Vogfjörð, K. S., Hjaltadóttir, S., Kjartansson, E., Roberts, M. J., and Slunga, R. (2009). "Interpreting seismic signals from Icelandic volcanoes," in Proceedings of the Conference on Earthquakes and Pre-Earthquake Processes, Reykjavík.

Ward, P. L., and Björnsson, S. (1971). Microearthquakes, swarms and the geothermal areas of Iceland. J. Geophys. Res. 76, 3953-3982. doi: 10.1029/ jb076i017p03953

Wessel, P., Luis, J. F., Uieda, L., Scharroo, R., Wobbe, F., Smith, W. H. F., et al. (2019). The generic mapping tools version 6. Geochem. Geophys. Geosyst. 20, 5556-5564. doi: 10.1029/2019GC008515

White, R. S., Drew, J., Martens, H. R., Key, J., Soosalu, H., and Jakobsdóttir, S. S. (2011). Dynamics of dyke intrusion in the mid-crust of Iceland. Earth Planet. Sci. Lett. 304, 300-312. doi: 10.1016/j.epsl.2011.02.038

Wolfe, C. J., Bjarnason, I. T. H., VanDecar, J. C., and Solomon, S. C. (1997). Seismic structure of the Iceland mantle plume. Nature 385, 245-247. doi: $10.1038 / 385245 \mathrm{a} 0$
Wright, T. J., Sigmundsson, F., Ayele, A., Belachew, M., Brandsdottir, B., Calais, E., et al. (2012). Geophysical constraints on the dynamics of spreading centres from rifting episodes on land. Nat. Geosci. 5, 242-250. doi: 10.1038/NGEO1428

Conflict of Interest: The authors declare that the research was conducted in the absence of any commercial or financial relationships that could be construed as a potential conflict of interest.

Copyright (c) 2021 Einarsson and Brandsdóttir. This is an open-access article distributed under the terms of the Creative Commons Attribution License (CC BY). The use, distribution or reproduction in other forums is permitted, provided the original author(s) and the copyright owner(s) are credited and that the original publication in this journal is cited, in accordance with accepted academic practice. No use, distribution or reproduction is permitted which does not comply with these terms. 